\title{
Optimization \& Demonstration of a Solid Oxide Regenerative Fuel Cell System
}

Technical Progress Report - Year 1 October 2003 - September 2004

Prepared for: The United States Department of Energy National Energy Technology Laboratory

Principal Investigator: James F. McElroy

Project Managers: Darren B. Hickey Fred Mitlitsky

Issued: December 2004

Cooperative Agreement: DE-FC26-03NT41854

Ion America Corporation Moffett Field, California 


\section{DISCLAIMER}

This report was prepared was prepared as an account of work sponsored by an agency of the United States Government. Neither the United States Government nor any agency thereof, nor any of their employees, makes any warranty, express or implied, or assumes any legal liability or responsibility for the accuracy, completeness, or usefulness of any information, apparatus, product, or process disclosed, or represents that its use would not infringe privately owned rights. Reference herein to any specific commercial product, process, or service by trade name, trademark, manufacturer, or otherwise does not necessarily constitute or imply its endorsement, recommendation, or favoring by the United States Government or any agency thereof. The views and opinions of authors expressed herein do not necessarily state or reflect those of the United States Government or any agency thereof. 


\begin{abstract}
Single cell solid oxide regenerative fuel cells (SORFCs) have been demonstrated for over 1000 hours of operation at degradation rates as low as $0.5 \%$ per thousand hours for current densities as high as $300 \mathrm{~mA} / \mathrm{cm}^{2}$. Efficiency levels (fuel cell power out vs. electrolysis power in) have been demonstrated in excess of $80 \%$ at $100 \mathrm{~mA} / \mathrm{cm}^{2}$. All testing has been performed with metallic based interconnects and non-noble metal electrodes in order to limit fabrication costs for commercial considerations. The SORFC cell technology will be scaled up to a $1 \mathrm{~kW}$ sized stack which will be demonstrated in Year 2 of the program.

A self contained SORFC system requires efficient thermal management in order to maintain operating temperatures during exothermic and endothermic operational modes. The use of $\mathrm{LiF}$ as a phase change material (PCM) was selected as the optimum thermal storage medium by virtue of its superior thermal energy density by volume. Thermal storage experiments were performed using LiF and a simulated SORFC stack. The thermal storage concept was deemed to be technically viable for larger well insulated systems, although it would not enable a high efficiency thermally self-sufficient SORFC system at the $1 \mathrm{~kW}$ level.
\end{abstract}




\section{TABLE OF CONTENTS}

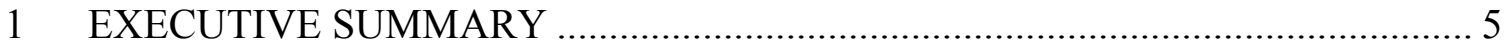

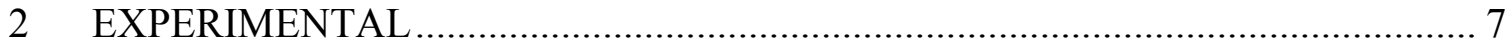

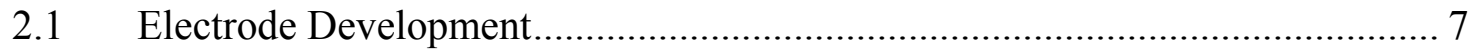

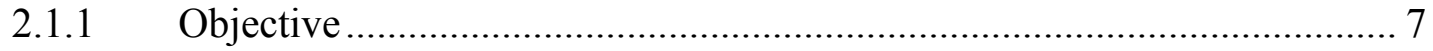

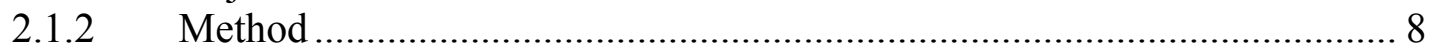

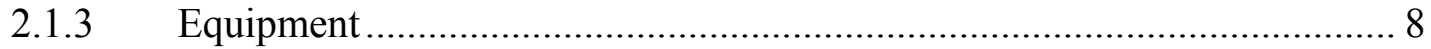

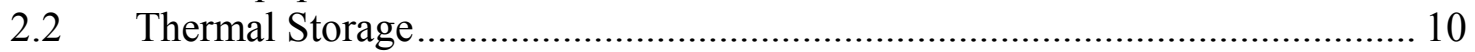

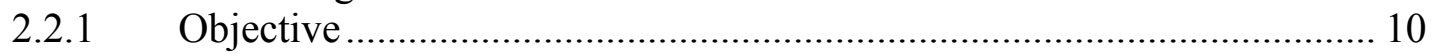

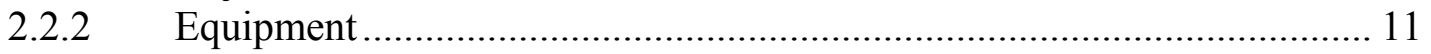

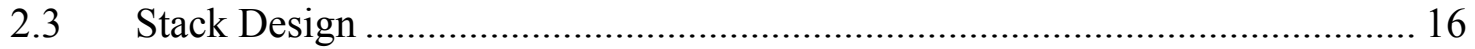

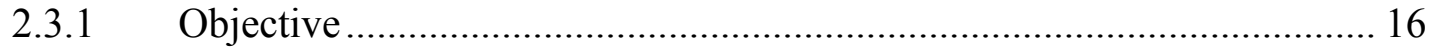

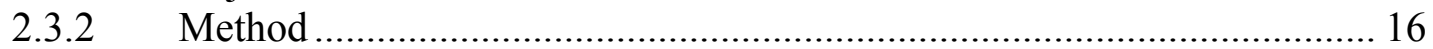

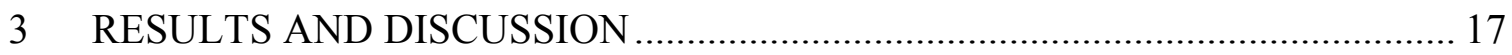

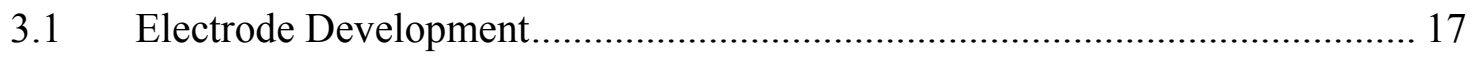

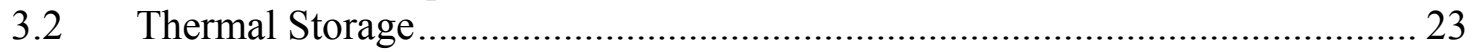

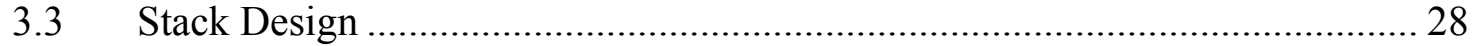

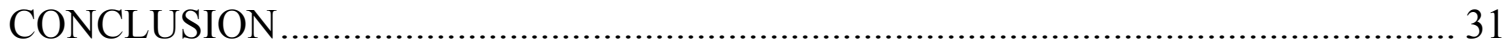

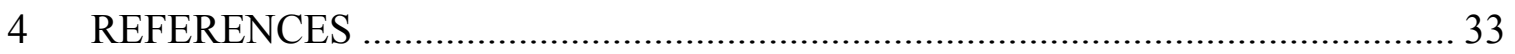

$5 \quad$ LIST OF ACRONYMS AND ABBREVIATIONS ............................................. 34 


\section{TABLE OF FIGURES}

Figure 1 Solid model of the test station.

Figure 2 SORFC test station process flow diagram...................................................... 10

Figure 3 Schematic of the thermal storage experimental setup ..................................... 11

Figure 4 Piping and instrumentation diagram for the thermal storage experimental setup

Figure 5 Design (inches) of the LiF cartridge showing three ports for loading LiF and

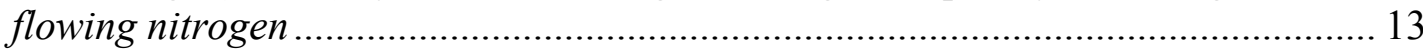

Figure 6 Typical cooling curves for the solidification of LiF in a cartridge facing a stack simulator.

Figure 7 Snapshot of a LabView screen display during a LiF crystallization experiment

Figure 8 Cell performance goals

Figure 9 Definition of electrochemical voltage efficiency (EVE) ................................... 17

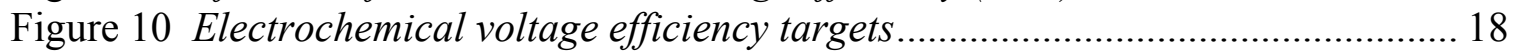

Figure 11 Definition of degradation (i.e. EVE loss per 1000 hours).............................. 18

Figure 12 Table of results from SORFC cell life cycle testing. (Test number $2^{P t}$ is Platinum baseline cell)

Figure 13 SORFC-013 Life Cycle Test at $850^{\circ} \mathrm{C}, 30 \%$ steam $/ 300 \mathrm{sccm} \mathrm{H}_{2}$ flow, $750 \mathrm{sccm}$ air flow. The cell was operated at $100 \mathrm{~mA} / \mathrm{cm}^{2}$ from 100-836 hours, then at $300 \mathrm{~mA} / \mathrm{cm}^{2}$ from 836-1200 hours. Potential above $1.0 \mathrm{~V}$ represents the charge or electrolysis mode, below $1.0 \mathrm{~V}$ represents the discharge or fuel cell mode. 20

Figure 14 SORFC-016 Initial Polarization Curve at 120 hours. The test conditions were $850^{\circ} \mathrm{C}, 30 \%$ steam $/ 300 \mathrm{sccm} \mathrm{H}_{2}$ flow, $750 \mathrm{sccm}$ air flow. Positive current represents the discharge or fuel cell mode, negative current represents the charge or electrolysis mode.

Figure 15 SORFC-016 Life Cycle Test at $850^{\circ} \mathrm{C}, 30 \%$ steam $/ 300 \mathrm{sccm} \mathrm{H}_{2}$ flow, $750 \mathrm{sccm}$ air flow. The cell was operated at $100 \mathrm{~mA} / \mathrm{cm}^{2}$ from $120-450$ hours, then at $200 \mathrm{~mA} / \mathrm{cm}^{2}$ from 450-680 hours. Potential above $1.0 \mathrm{~V}$ represents the charge or electrolysis mode, below $1.0 \mathrm{~V}$ represents the discharge or fuel cell mode.

Figure 16 Comparison of oxidant catalyst compositions in electrolysis mode at 200 Hours and $850^{\circ} \mathrm{C}$. Active Area of $10 \mathrm{~cm}^{2}, 30 \%$ Steam $/ 300 \mathrm{sccm} \mathrm{H}, 750 \mathrm{sccm}$ Air .... 22

Figure 17 Comparison of oxidant catalyst compositions in fuel cell mode at 200 Hours and $850^{\circ} \mathrm{C}$. Active Area of $10 \mathrm{~cm}^{2}, 30 \%$ Steam $/ 300 \mathrm{sccm} \mathrm{H}, 750 \mathrm{sccm}$ Air.

Figure 18 Thermal Energy Storage Densities of Several Candidate Phase Change Materials (PCMs)

Figure 19 ASPEN Plus model for SORFC system in fuel cell mode shows $454 \mathrm{~W}$ for thermal storage.

Figure 20 Typical melt and crystallization temperature profiles for a LiF thermal storage experiment.....

Figure 21 Expanded view of the temperature profiles during LiF crystallization........... 27

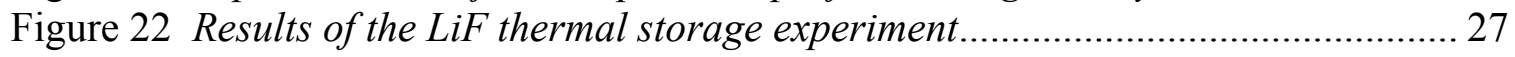

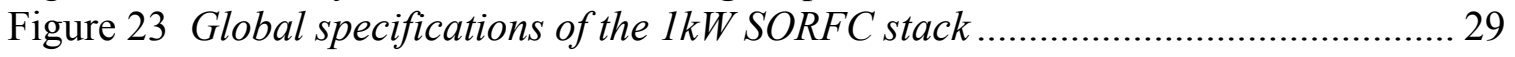

Figure 24 Interconnects fabricated for SORFC stack testing ...................................... 30 


\section{EXECUTIVE SUMMARY}

Solid Oxide Regenerative Fuel Cells (SORFC's) offer the promise of high efficiency, low cost, and impressive specific energy $(\mathrm{kW}-\mathrm{hr} / \mathrm{kg})$ in a single reversible stack. The overall objective of the work being performed is to optimize and demonstrate a closed SORFC system for cost and efficiency and take this concept closer to practical use. SORFC systems are attractive for utility peak load shaving, uninterruptible power systems, and military solar-powered aircraft. In combination with intermittent solar power, the SORFC can be used in remote applications to provide continuous power. The key objectives of this work include the following:

- Development of electrode materials that can perform adequately in both the electrolyzer (charge) and fuel cell (discharge) modes, have long life, and are affordable (Year 1).

- Development of novel thermal control schemes that allow for a high overall efficiency for the system by optimum utilization of the heat generated (Year 1).

- Design, development, and testing of a $1 \mathrm{~kW}$ SORFC stack (Year 2).

- Design, development and demonstration of a complete SORFC system breadboard for more than 500 hours and 20 regenerative cycles at greater than $60 \%$ energy storage efficiency (Year 3).

A baseline was established for SORFC performance using platinum-based electrodes in a button cell at $71.6 \%$ initial electrochemical voltage efficiency (fuel cell voltage divided by electrolysis cell voltage) with a degradation rate (change in cycle efficiency) of $4 \%$ per 1000 hours after 800 hours and 26 charge/discharge cycles while operating at 100 $\mathrm{mA} / \mathrm{cm}^{2}$. This accomplishment (12/03) set the standard by which cells with non-noble metal catalysts could be compared.

Screening tests were performed on fourteen SORFC button cells with non-noble metal electrodes. The best initial electrochemical voltage efficiency of $85 \%$ was demonstrated on the best variant. This accomplishment (3/04) significantly exceeded the platinumbased electrode standard and the program goals.

Lifetime tests were performed on a number of SORFC button cells with non-noble metal electrodes, which had demonstrated acceptable initial performance levels. The best variant established performance stability within $0.5 \%$ per 1000 hours. This accomplishment (6/04) also significantly exceeded the platinum-based electrode standard and the program goals.

The molten salt lithium fluoride (LiF) was selected, via a literature search and ASPEN Plus modeling, as the most suitable phase change material for the thermal storage experiments. These experiments were conducted using a simulated $1 \mathrm{~kW}$ stack in order to demonstrate the technology. Our thermal analysis and testing confirmed that lithium fluoride is an effective compound for thermal storage since it has an ideal phase change temperature $\left(848^{\circ} \mathrm{C}\right)$ and very high specific latent heat of fusion $(1.04-1.08 \mathrm{~kJ} / \mathrm{g})$. 
The measured heat loss from our thermal storage test setup employing lithium fluoride as the phase change material was $491 \mathrm{~W}$, which was in excellent agreement with the estimated $490 \mathrm{~W}$ loss using COSMOS Works computational fluid dynamics (CFD) modeling. According to COSMOS Works, improved insulation could reduce the loss by a factor of 2, but this would still be a significant fraction of the $454 \mathrm{~W}$ of heat available for storage in fuel cell mode as determined by modeling using ASPEN Plus (chemical process tool for the design, simulation, and optimization of process plants). The analysis shows that the planned $1 \mathrm{~kW}$ SORFC has too low a rating to be thermally self sufficient with heat storage alone. For this reason it is planned to continue the project without integrating thermal storage with the $1 \mathrm{~kW}$ stack. However design features within the stack to allow thermal storage integration in the future will be provided for higher rated systems.

The project is on track to demonstrate a $1 \mathrm{~kW}$ SORFC stack by the end of Year 2. Further electrode optimization and process scale-up development work will continue for the purposes of producing a well characterized and robust stack. Larger footprint cells $\left(>65 \mathrm{~cm}^{2}\right)$ will be tested in single cell and short stack tests with the goal to reduce contact resistance and gas flow field non-uniformity. The $1 \mathrm{~kW}$ stack has been specified at 100 cells, operating at $200 \mathrm{~mA} / \mathrm{cm}^{2}$ with air stoichiometries as low as 2.0 . This will place high demands on the air flow fields of the stack and will be at the top of the development task in Year 2. 


\section{EXPERIMENTAL}

There were three main experimental objectives for Year 1 of this project. The first was the demonstration of workable solid oxide regenerative fuel cells with the emphasis on electrode/catalyst development. The second objective was to test and demonstrate the viability of a high temperature thermal storage concept used to store heat during the exothermic fuel cell mode and to be discharged during the endothermic electrolysis mode. The design of an SORFC stack with larger active areas $\left(<65 \mathrm{~cm}^{2}\right)$, taking into account results from the experimental tasks, was the other main objective.

\subsection{Electrode Development}

\subsubsection{Objective}

The purpose of this task was to develop non-noble metal electrodes that can operate in both electrolysis and fuel cell modes as well as meeting the performance and degradation targets specified by the project goals. Electrodes would initially be run through a short screening test before determining whether or not to continue the test. If the cell with the particular electrode set reached acceptable initial performance targets it would then continue testing up to a minimum 750 hours of operation and 30 charge/discharge cycles.

Noble metal, platinum based, electrodes were initially fabricated and tested in order to establish a stable baseline performance. Non-noble metal electrodes were then fabricated and tested and could therefore be compared directly with the platinum based cells and the overall project performance goals. A minimum number of 15 alternative electrode configurations were to undergo screening tests and those of which met the initial performance targets continued as a longer term life cycle test.

The selection of electrode materials was based on literature searches as well as a large portion of SOFC expertise from a variety of industry specialists. The target operating temperature of $850^{\circ} \mathrm{C}$ combined with degradation goals of less than $2 \%$ per 1000 hours leads the material selection process to more stable elements that have proven track records at high temperatures. Therefore most of the effort was focused on the more traditional SOFC materials and how they perform in a regenerative operation. The general approach was to study electrode systems containing mixed ionic/electronic conductors (MIEC's). These electrode systems offer the potential for high performance and high electrochemical reversibility [Yamashita]. The primary electronic conducting element for the anode side was Ni kept under reducing conditions. More options exist on the cathode side with materials under consideration being LSM, LSC [Eguchi], LCC, LSCF, and other similar perovskite structures. Ionic conducting materials for either side of the cell included 8YSZ, 3YSZ, GDC and ScSZ. Combinations of these elements were tested in order to determine a short list of promising candidates.

The electrode performance testing was done using an SOFC platform developed by Ion America Corporation. This established technology developed for the SOFC program was 
modified along with the test rig infrastructure to accommodate the regenerative tests. This approach was planned to minimize the development time needed to get the project up and running.

\subsubsection{Method}

The electrode process began with raw powder, which was then processed into ink that was suitable for screen printing. The electrodes were then screen printed onto $50 \mathrm{~mm}$ diameter disks of $8 \%$ yttria doped zirconia electrolytes (8YSZ) with an active area of $10 \mathrm{~cm}^{2}$. These ceramic disks were 300 micrometers thick $(0.016$ inches $)$ with a uniform surface roughness. The electrolyte dimensions remained fixed for this task of the project so that it would not interfere with electrode comparisons. The complete cell with electrodes was then placed between two metallic manifolds with a glass based seal running around the circumference. To ensure good electrical contact between the electrode and the manifold a contact layer was screen printed onto the metallic manifold. A protective coating was also used on the air/oxygen manifold in order to prevent contamination from chromium oxide. Alumina cups were placed around the manifolds for alignment and compression support. This cell assembly was then placed inside a furnace on a test station.

The cell assembly was heated up to $950^{\circ} \mathrm{C}$ at $3{ }^{\circ} \mathrm{C}$ per minute with 1 hour dwell at $300^{\circ} \mathrm{C}$ to accommodate the binder burnout phase. The assembly was held at $950^{\circ} \mathrm{C}$ for two hours to sinter the glass seals in place before cooling down to the $850^{\circ} \mathrm{C}$ operating temperature. Once at operating temperature the fuel side of the assembly was reduced in hydrogen over a 24 hour period. Once the reduction procedure was complete, steam was added to the hydrogen stream of $300 \mathrm{sccm}$ up to $30 \%$ by volume. Air flow was maintained over the air/oxygen side of the cell at $750 \mathrm{sccm}$. This established an open circuit voltage (OCV) of $0.966 \mathrm{~V}$. The cell was then characterized using the AC impedance technique before beginning regenerative cycle operation.

The gas streams on both sides of the cell remained fixed throughout the regenerative operation in order to maintain a constant Nernst potential (OCV) across the cell. Therefore the fuel side of the fuel cell mode becomes the steam source during the electrolysis mode. The air also continued to flow throughout both modes of operation, again to maintain a constant Nernst potential even during the electrolysis or oxygen production mode. The current therefore reversed direction between operational modes. Once the initial characterization was complete the test station was placed on automated operation, switching/cycling the cell from electrolysis mode to fuel cell mode every 12 hours. During the switch-over period a complete polarization curve was run from $0.5 \mathrm{~V}$ in fuel cell mode, up to $1.8 \mathrm{~V}$ in electrolysis mode.

\subsubsection{Equipment}

Four SORFC test stations were designed and built at the start of the program. Two stations shared a common frame, computer and data logger for reasons of cost saving and floor space reduction. A solid model of the test rig is seen in Figure 1. 
The electrical systems include the furnace, power supply, data logger and central computer. The power supply also has the capability to operate as an electronic load and therefore by simply switching the direction of the current the cell can be controlled in fuel cell or electrolysis mode. The computer operates LabView software which controls most functions of the test station, e.g., valves, mass flow controllers, power supply, data logger and furnace. The experimental profile is pre-programmed into LabView which then controls the test automatically.

The gas supplies are controlled via mass flow controllers. Air is supplied to the oxygen side of the cell as well as to the pneumatic compression system which provides a constant compressive load on the cell. Mass flow meters are also installed on the exhaust of the oxidant side to monitor oxygen production from the electrolysis mode. The fuel system supplies hydrogen and inert nitrogen to the cell. During operation hydrogen passes through a humidifier which can be controlled to provide a specified steam content into the cell. Typically a mixture of $70 \%$ hydrogen $/ 30 \%$ steam is used for both modes of operation. The water system operates on a recycle loop, where the water in the fuel exhaust is condensed and collected back in the humidifier supply reservoir. The process flow diagram can be seen in Figure 2.

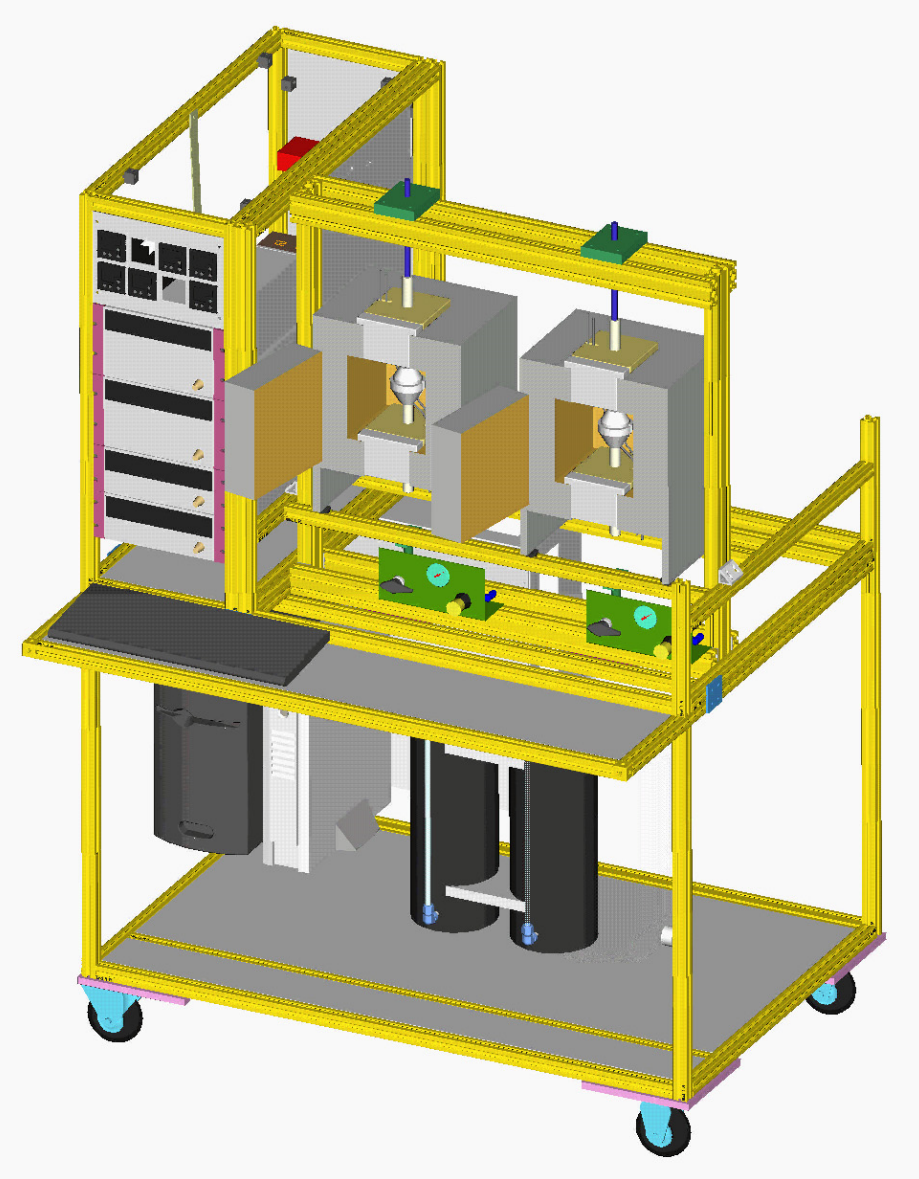

Figure 1 Solid model of the test station 


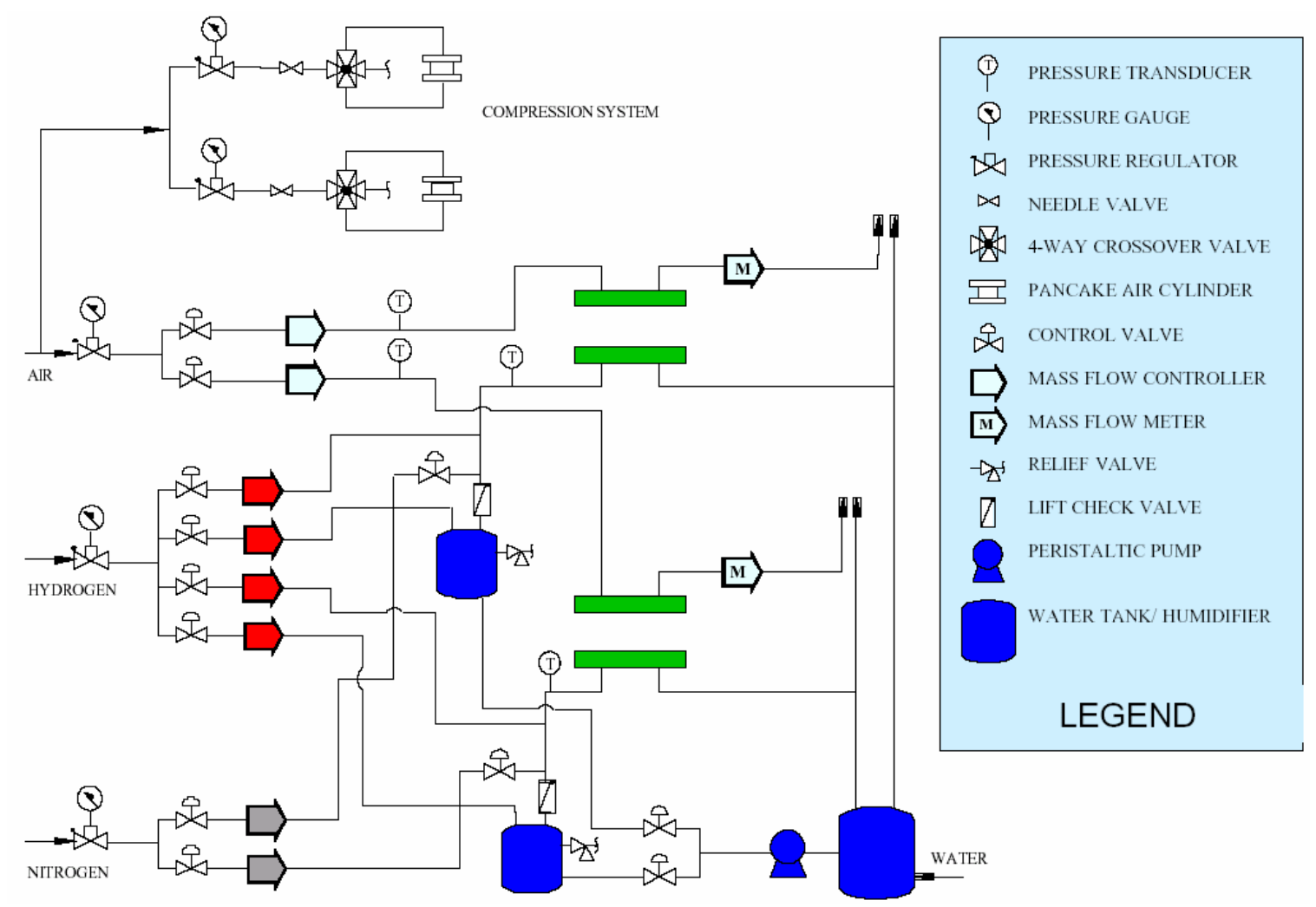

Figure 2 SORFC test station process flow diagram

\subsection{Thermal Storage}

\subsubsection{Objective}

The purpose of this task was to evaluate novel thermal control schemes that allow for a high overall efficiency for the SORFC system by proper utilization of the heat generated. Thermal management approaches were considered for storing exothermic fuel cell mode waste heat for later use in maintaining operating temperatures during endothermic electrolysis operation. Models were analyzed for viability and performance and a trade study was conducted to select the best options.

A thermal storage test rig was designed, assembled, and used to obtain performance data for a selected thermal storage option at system-relevant conditions. The data was used to help establish the feasibility of thermal storage options based primarily on operating temperature range $\left(800-900^{\circ} \mathrm{C}\right)$ and high thermal storage density with consideration for material cost and material safety. The key goals of this task were: 1) downselect a thermal storage concept capable of storing high quality heat for use in electrolysis mode; and 2) use a combination of modeling and laboratory experiments to assess the feasibility of maintaining a thermally self-sustaining SORFC system at the $1 \mathrm{~kW}$ level, which will be potentially specified in Year 2 and potentially demonstrated in Year 3 of this program. 
The key figures of merit for selecting the thermal storage system are:

- Density - High volumetric energy density of high quality heat

- Efficiency - Good heat transfer into and out of the storage medium with low losses

- Stability - Good reversibility with high cycle life

- Cost - Low cost and easy to control

High volumetric energy density of high quality heat is required to minimize the impact of thermal storage on the size of the high temperature zone (hot box). This was determined to be the most critical figure of merit for achieving a feasible design for a thermally selfsustaining $1 \mathrm{~kW}$ SORFC system, since thermal losses from the hot box will increase as the size of the hot box is increased.

\subsubsection{Equipment}

The spatial arrangement of the thermal storage system is determined by the geometry of the SORFC stack with consideration for gas and electrical connections. Thermal storage can be a rectangular box with one rectangular face in close contact with one side of a solitary SORFC stack, or as a rectangular box sandwiched between two adjacent SORFC stacks, or preferably as two separate boxes on two faces of a single stack. The schematic for the thermal storage experimental set-up is shown in Figure 3.

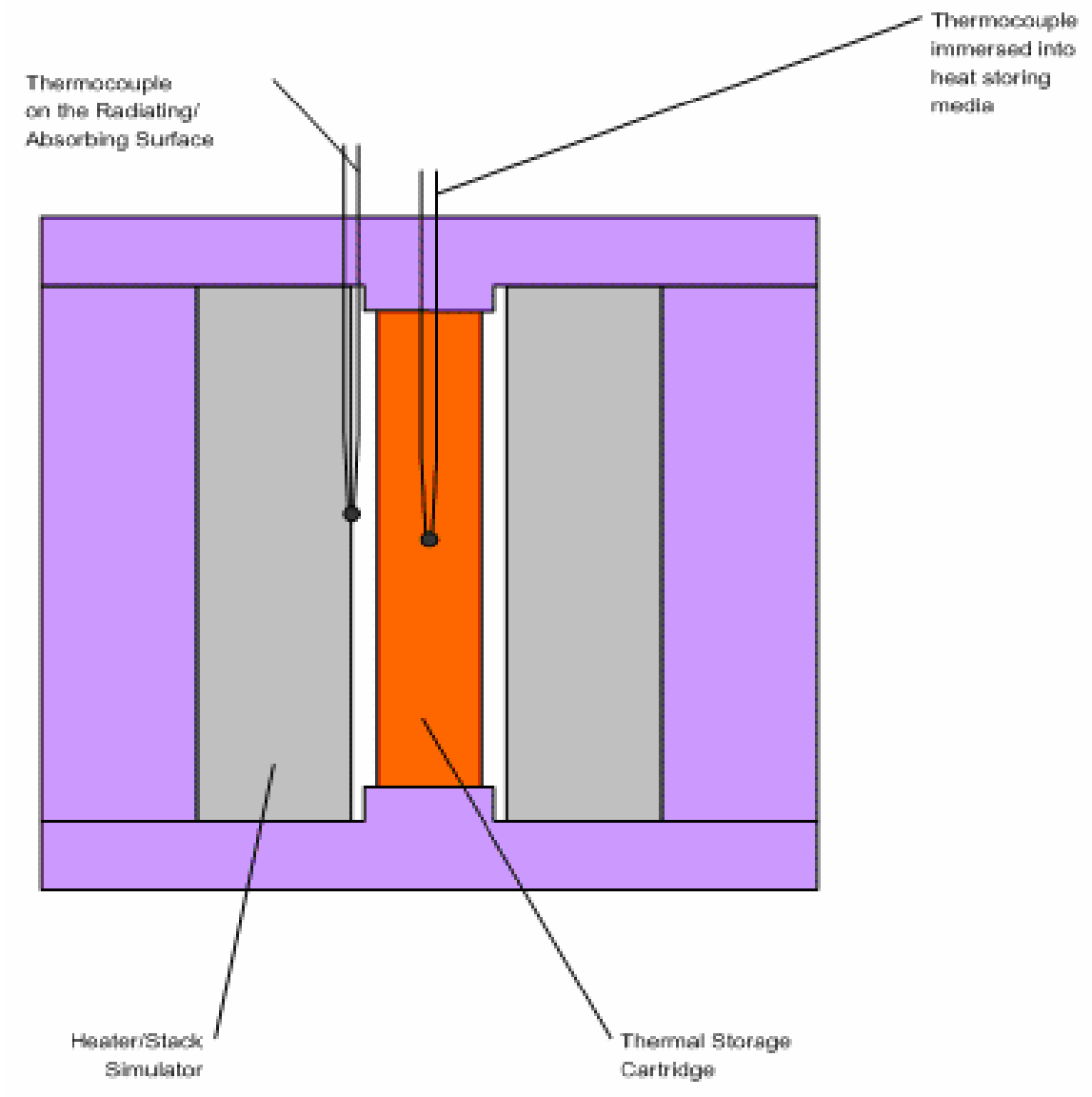

Figure 3 Schematic of the thermal storage experimental setup 
The piping and instrumentation diagram (P\&ID) for the thermal storage experiment is shown in Figure 4. Haynes Alloy 188 (HA-188) was used as the material of construction for the box that contained the LiF in our experiments, as was done by NASA [Dreshfield, Whittenberger] for LiF experiments, such as the first Thermal Energy Storage (TES-1) experiment that was successfully flown as part of a payload on the Columbia Shuttle STS-62 in early 1994. Although NASA experiments were done using an HA-188 box that was permanently welded shut, we chose to keep the box open with three ports (one for filling the $\mathrm{LiF}$, and two flowing nitrogen over the $\mathrm{LiF}$ as shown in Figure 5). Our decision to use three ports was made to reduce fabrication cost, by avoiding the need to weld the box in vacuum or inert ambient with $\mathrm{LiF}$ in place [Gnadt].

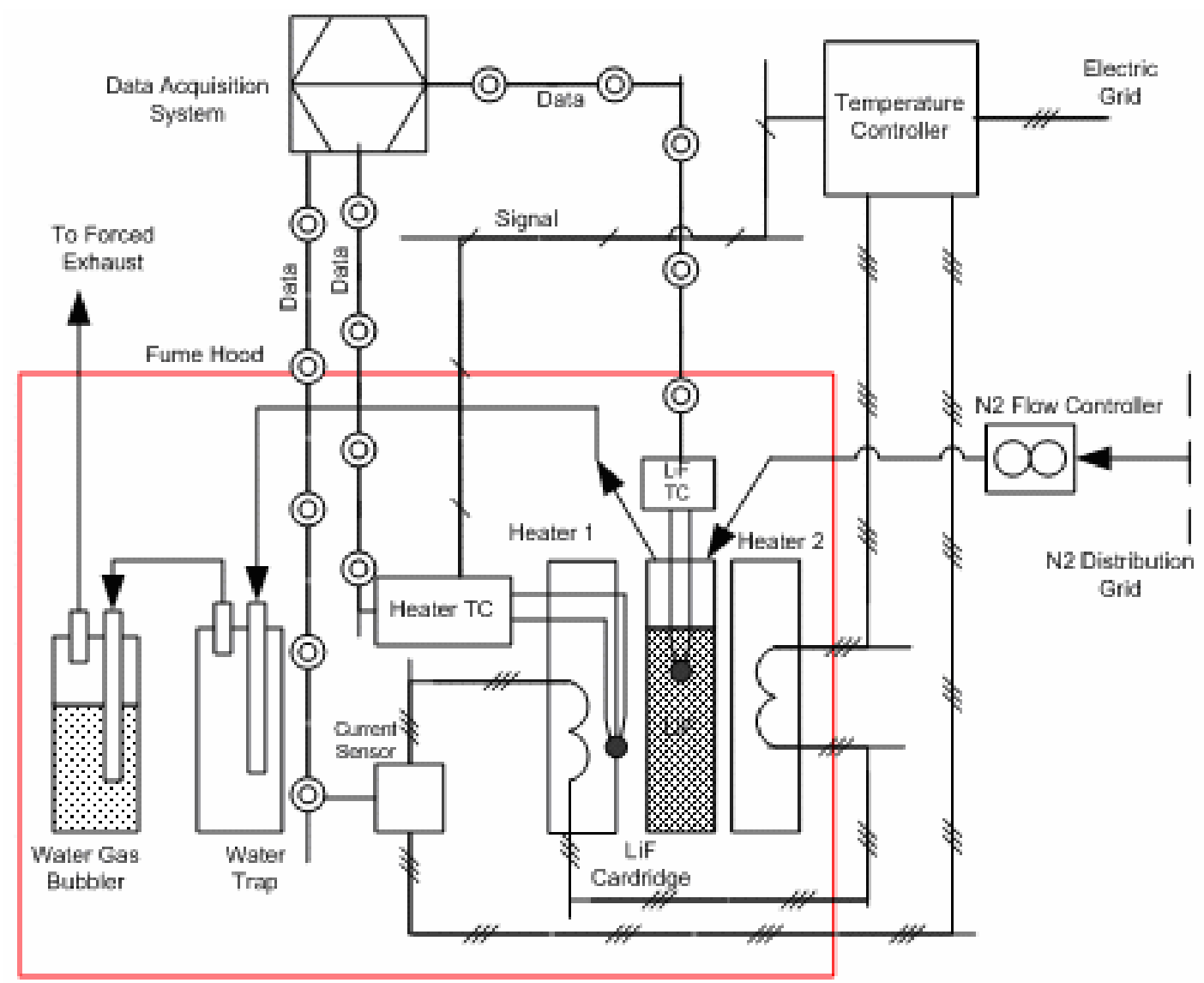

Figure 4 Piping and instrumentation diagram for the thermal storage experimental setup

The thermocouple "Heater TC" was mounted on the surface of one of the heaters and used to control the temperature of the radiating/absorbing surface through a temperature controller that supplied power to the heater coils connected in series. The "LiF TC" thermocouple was inserted into a metal tube extending approximately to the middle of the $\mathrm{LiF}$ melt. This thermocouple was used to determine the average temperature of the PCM, and to estimate the start and the end of the melting/crystallization cycle. The Data Acquisition System was used to collect outputs from the thermocouples, current sensor, and temperature controller. The current sensor was used to measure the power introduced 
into the stack simulator heaters as a function of time. Dry nitrogen gas was flowed $(\sim 100 \mathrm{cc} / \mathrm{min})$ over the melt surface to prevent reaction of LiF with ambient humidity, and to remove low levels of $\mathrm{LiF}$ vapor. The $\mathrm{LiF}$ cartridge nitrogen outlet was connected to a water trap and then to a water bubbler to capture impurities and prevent LiF vapor from escaping.

A key goal of the experiment was to determine the actual losses to the surroundings in a realistic setting and to determine parameters that would help characterize the heat transfer inside the thermal storage cartridge. The heat losses can be determined using two approaches. In one approach, the system is brought close to equilibrium just above or below the melting point and the power that is supplied to the heaters from the temperature controller is measured. If the system is above/below the phase change temperature and no heat related to phase transition is involved the power from the heaters has to be equal to the heat losses to maintain system equilibrium. The results can be then be linearized to the actual temperatures during the crystallization process. The other approach is to determine the crystallization time period from the crystallization temperature curve usually using the derivative of the temperature vs. time dependence. The overall latent heat is known from the mass of the salt loaded in the storage and the latent heat of fusion of $\mathrm{LiF}$. That amount is equal to the amount of heat lost to the ambient during the crystallization time. The average heat loss can be determined by dividing the latent heat value by crystallization time.

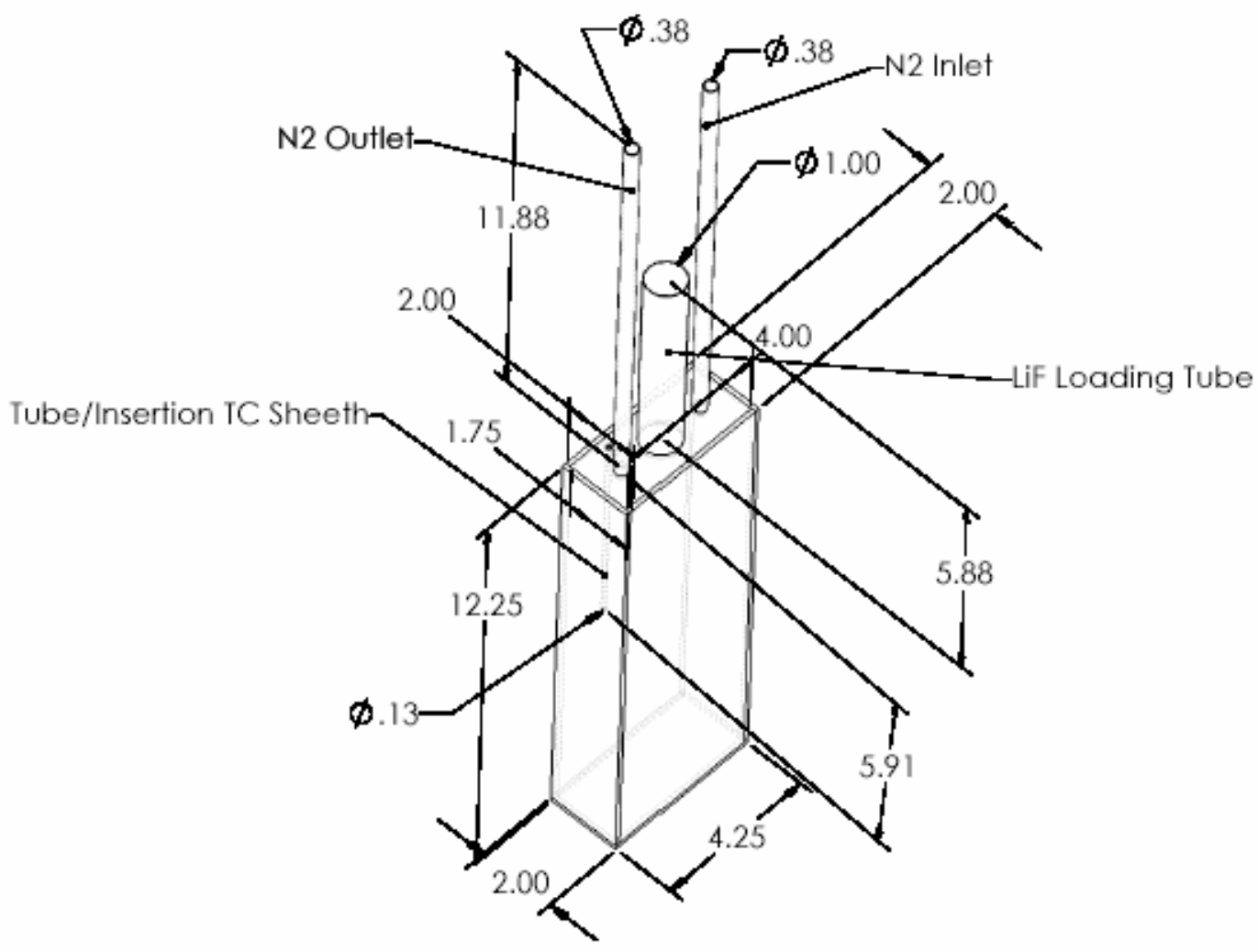

Figure 5 Design (inches) of the LiF cartridge showing three ports for loading LiF and flowing nitrogen 
The temperature of the solid-liquid system as measured by an immersed thermocouple is close to constant during the crystallization process. The heat flux to the ambient (heat losses) determines the crystallization rate and the heat of fusion is released at the rate equal to the heat losses maintaining the temperature distribution in the system close to equilibrium. The deviation in the temperature distribution is caused by the change in the solid/liquid ratio in the melt and is limited due to the small variation in thermophysical properties of the solid and liquid phases in close proximity to the phase change point. Figure 6 shows typical crystallization curves for the thermocouple immersed into the melt (red) and thermocouple attached to the adjacent surface of the stack simulator (blue).

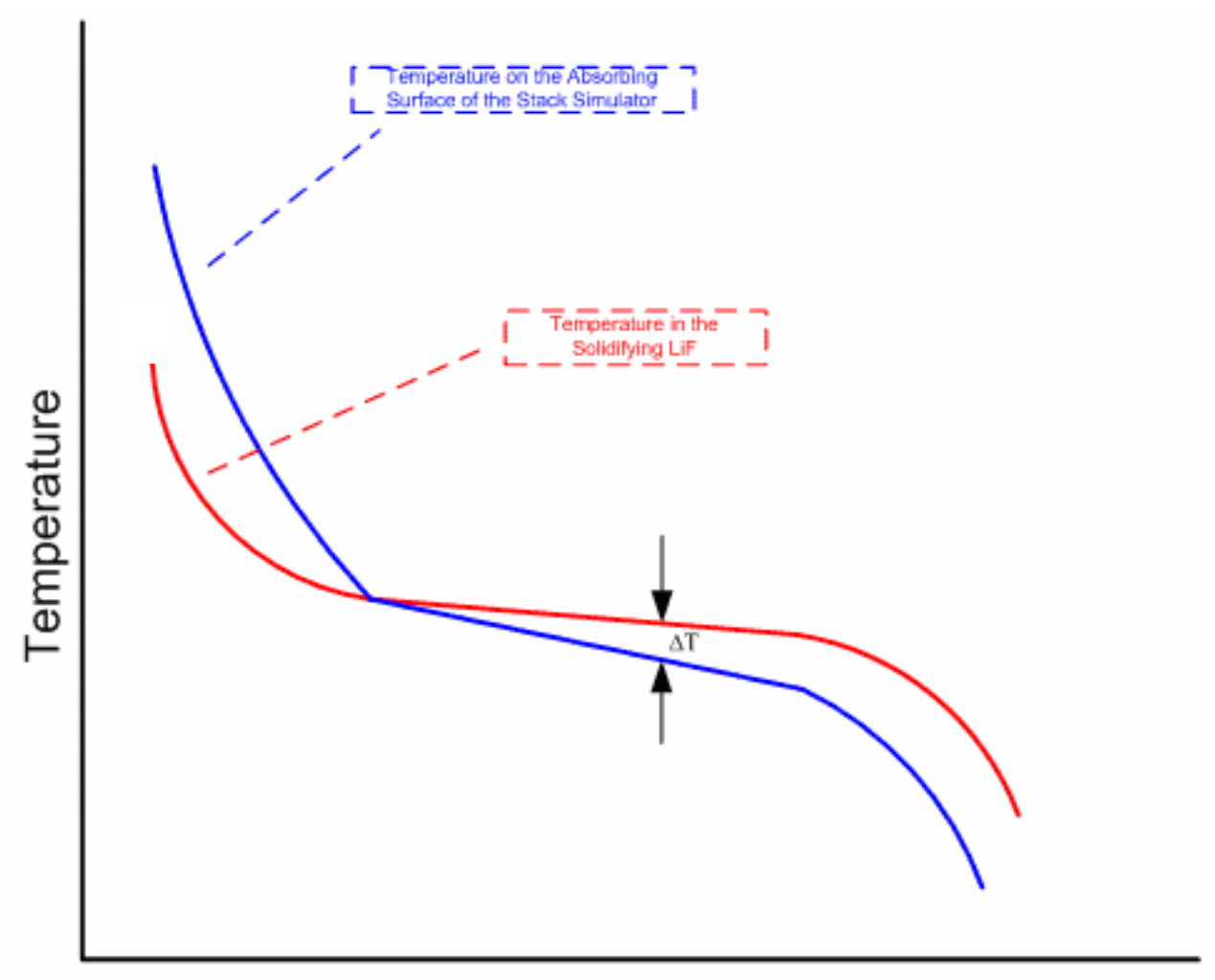

Time

Figure 6 Typical cooling curves for the solidification of LiF in a cartridge facing a stack simulator

In an actual SOFRC system employing thermal storage with a PCM, the rate of the latent heat release from the thermal storage $\mathrm{Q}_{\mathrm{S}}$ will be defined by the heat required to balance the endothermic electrolysis reaction $\mathrm{Q}_{\mathrm{E}}$ and the heat losses $\mathrm{Q}_{\mathrm{L}}$ :

$$
\mathrm{Q}_{\mathrm{S}}=\mathrm{Q}_{\mathrm{E}}+\mathrm{Q}_{\mathrm{L}}
$$

In test cases where the simulation does not involve the endothermic electrolysis reaction heat, the latent heat release from thermal storage is defined only by heat losses:

$$
\mathrm{Q}_{\mathrm{S}}=\mathrm{Q}_{\mathrm{L}}
$$


The temperature difference between the temperature in the melt and the temperature on the adjacent surfaces of the stack simulators ( $\Delta \mathrm{T}$ on Figure 6 ) is caused by the thermal resistance of the radiation heat transfer and by thermal resistance of the conduction/ convection heat transfer in the salt that depends on the solid/liquid ratio in the crystallizing salt.

The thermal storage cartridge was designed to store $2.4 \mathrm{~kg}$ of LiF. The stack simulators were made using ceramic fiber blocks with incorporated heating coils and the insulation included 2 inches of vitreous aluminosilicate fiber (Kaowool ${ }^{\circledR} \mathrm{S}$ blanket) flexible insulation followed by 4 inches of amorphous silica mixture (BTU Block ${ }^{\circledR}$ Board) insulation (both from Thermal Ceramics). N-type thermocouples were used to measure temperature profiles. The test rig was assembled and experiments were conducted in a fume hood. An HF/F $/ 2$ gas detector STX-PA from PureAire Monitoring Systems, Inc. with electrochemical sensor was used to monitor possible release of fluorine gas. Data was collected using Agilent 34970A Data Acquisition/Switch Unit and the experiment was controlled using custom LabView code and corresponding control hardware. A snapshot of a typical LabView screen display during a LiF crystallization experiment is shown in Figure 7.

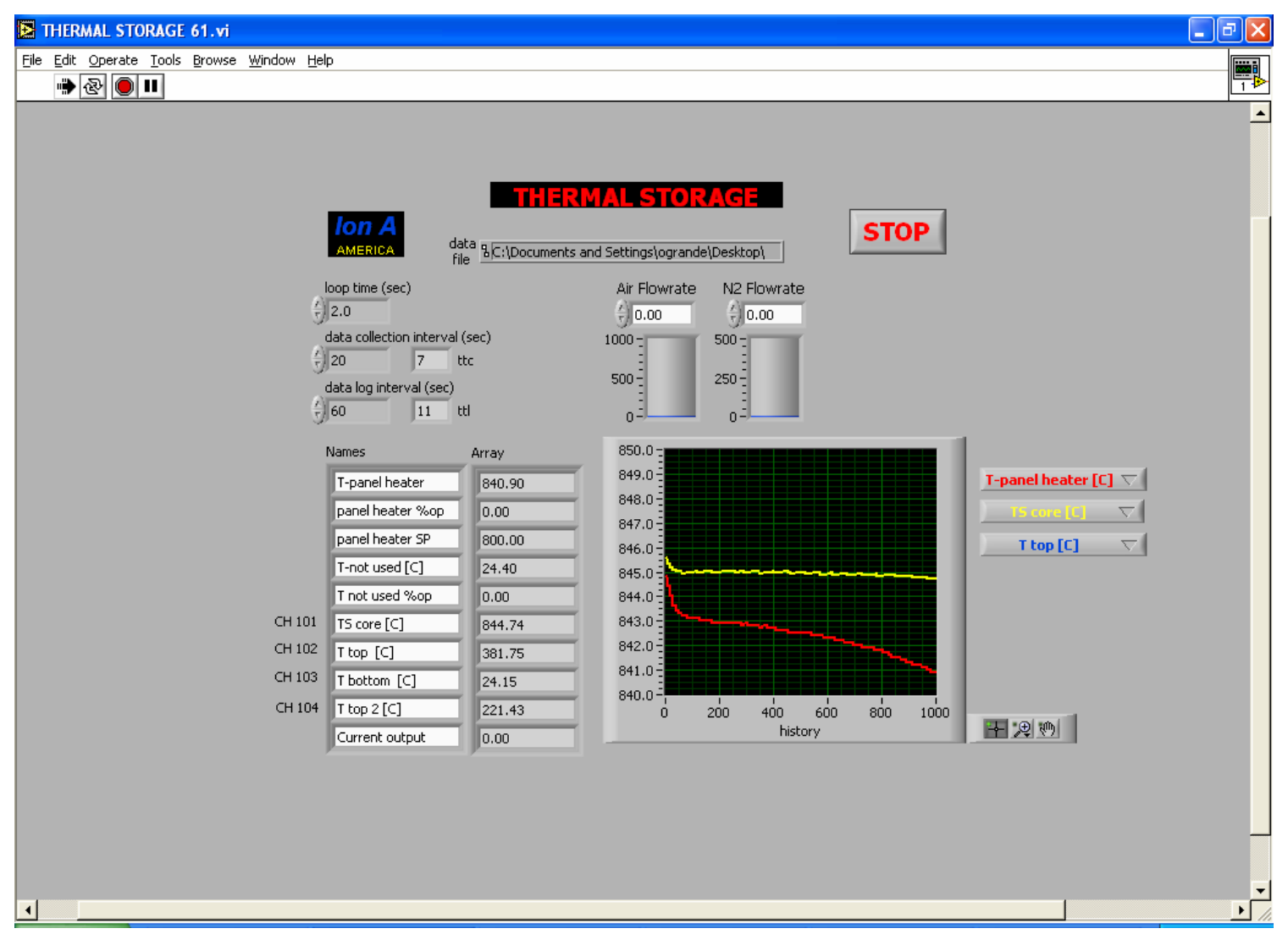

Figure 7 Snapshot of a LabView screen display during a LiF crystallization experiment 


\subsection{Stack Design}

\subsubsection{Objective}

The results from both the electrode development and thermal storage tasks are designed to feed into the design of an SORFC stack with a larger footprint. Short stacks will be operated using the initial design to assess the various issues associated with stack operation including flow uniformity, contact resistance, thermal cycle integrity and thermal gradients to name a few. The design will be tested and modified during Year 2 of the project with the goal of demonstrating a $1 \mathrm{~kW}$ SORFC stack.

\subsubsection{Method}

The global specification of the $1 \mathrm{~kW}$ stack, i.e. number of cells and thermal storage capacity, will be determined from the performance levels of the electrode development task and the thermal storage task. The cell structure itself, which includes the electrolyte, anode and cathode, will be selected from the $50 \mathrm{~mm}$ tests considering electrochemical efficiency, power output and degradation rates. The interconnect design and overall stack dimensions will be largely carried over from the SOFC program. The main modification to be made will be adapting the air side of the interconnect to be capable of operating at very high air utilization levels. This will be necessary in order to reduce the parasitic heat losses of the system so that the operational window of the thermal storage system can be extended. Advanced concepts such as current collection and flow field options will also be explored during the stack testing task.

Computational fluid dynamics (CFD) tools has also been used in order to better understand the flow field characteristics and pressure drops within the stack. These tools will help to identify the most critical aspects of the flow field with the aim to optimize flow uniformity both between each cell layer and also within each layer. 


\section{RESULTS AND DISCUSSION}

\subsection{Electrode Development}

The performance goals for the electrode development task were specified in the document; Supplemental Information Relative to Ion America's Proposal to DOE Solicitation NO. DE-PS26-02NT41613-08: Solid Oxide Regenerative Fuel Cell Performance Goals, dated September 15, 2003. The goals for cell voltage in both operational modes have been tabulated in Figure 8.

\begin{tabular}{|c|c|c|c|}
\hline & \multirow{2}{*}{$\begin{array}{c}\text { Fuel Cell Mode } \\
100 \mathrm{~m} A / \mathrm{cm}^{2}\end{array}$} & \multicolumn{2}{|c|}{ Electrolysis Mode } \\
\hline & & $100 \mathrm{~mA} / \mathrm{cm}^{2}$ & $200 \mathrm{~mA} / \mathrm{cm}^{2}$ \\
\hline V@0hrs & 0.800 & 1.140 & 1.300 \\
\hline V@ 1000 hrs & 0.784 & 1.163 & 1.326 \\
\hline$\Delta \mathrm{V} / \mathbf{1 0 0 0} \mathrm{hrs}$ & $\leq 2 \%$ & $\leq 2 \%$ & $\leq 2 \%$ \\
\hline
\end{tabular}

Figure 8 Cell performance goals

Because of the regenerative or reversible nature of an SORFC it is very useful to specify performance in terms of efficiency. Electrochemical voltage efficiency (EVE) is defined as the fuel cell voltage divided by the electrolysis voltage, given the current density of the cell remains constant over the two operational modes. This provides a simple and accurate efficiency measure of energy out over energy in. This definition is expressed in Figure 9.

$$
E V E=\frac{\text { Energy_Out }}{\text { Energy_In }}=\frac{V_{\text {fuelcell }}}{V_{\text {electrolysis }}}
$$

Figure 9 Definition of electrochemical voltage efficiency (EVE)

The EVE targets were also specified in the Solid Oxide Regenerative Fuel Cell Performance Goals document for two separate operational levels. These targets are listed in Figure 10.

By using the EVE, an absolute measure of the degradation rate can be calculated in terms of efficiency loss over time. The degradation rate is usually normalized to a period of 1000 hours. The definition of degradation rate is shown in Figure 11 where $t$ is time in hours. 


\begin{tabular}{|l|c|c|}
\hline & MODE 1 & MODE 2 \\
\hline $\begin{array}{l}\text { Fuel Cell } \\
\text { Current Density }\left(\mathbf{m A} / \mathbf{c m}^{2}\right)\end{array}$ & 100 & 100 \\
\hline $\begin{array}{l}\text { Electrolysis } \\
\text { Current Density }\left(\mathbf{m A} / \mathbf{c m}^{2}\right)\end{array}$ & 100 & 200 \\
\hline $\begin{array}{l}\text { Electrochemical Voltage Efficiency } \\
\text { (EVE) }\end{array}$ & $70.0 \%$ & $61.5 \%$ \\
\hline
\end{tabular}

Figure 10 Electrochemical voltage efficiency targets

$$
\text { Degradation }=\left(E V E_{1}-E V E_{2}\right) \times \frac{1000}{\left(t_{2}-t_{1}\right)}
$$

Figure 11 Definition of degradation (i.e. EVE loss per 1000 hours)

A total of sixteen $50 \mathrm{~mm}$ cell tests were completed over the phase I period. The results from the cells that met the initial performance targets and continued running as longer term Life Cycle Tests are shown in Figure 12. The data reported on these cells is the initial EVE and the degradation normalized to percent per thousand hours. The cells that have not been reported either failed to meet initial performance targets and were too unstable to obtain reliable data, or the test was compromised by external factors, such as a general power failure early in the life of the test, which again produced unreliable results. All cells were operated using $750 \mathrm{sccm}$ air flow and $300 \mathrm{sccm} \mathrm{H}_{2}$ flow.

\begin{tabular}{|c|c|c|c|c|c|c|}
\hline \multirow{3}{*}{$\begin{array}{c}\text { SORFC } \\
\text { Test } \\
\text { Number } \\
\end{array}$} & \multicolumn{2}{|c|}{$100 \mathrm{~mA} / \mathrm{cm}^{2}$} & \multicolumn{2}{|c|}{$200 \mathrm{~mA} / \mathrm{cm}^{2}$} & \multicolumn{2}{|c|}{$300 \mathrm{~mA} / \mathrm{cm}^{2}$} \\
\hline & EVE & Degradation & EVE & Degradation & EVE & Degradation \\
\hline & $\%$ & $\% / 1000$ hrs & $\%$ & $\% / 1000$ hrs & $\%$ & $\% / 1000$ hrs \\
\hline $2^{\mathrm{Pt}}$ & 71.6 & 4 & & & & \\
\hline 5 & 81.8 & 20 & & & & \\
\hline 6 & 82.4 & 4 & & & & \\
\hline 7 & 82.5 & 1 & & & & \\
\hline 8 & 75.4 & 0.7 & & & & \\
\hline 9 & 78.0 & 1 & & & & \\
\hline 11 & 83.2 & 0.3 & & & & \\
\hline 13 & 81.6 & 0.5 & & & 52.3 & 0.5 \\
\hline 14 & 81.8 & 0.8 & 66.2 & 2 & & \\
\hline 15 & 82.8 & 2 & 67.2 & 3 & & \\
\hline 16 & 82.2 & 2 & 66.5 & 2 & & \\
\hline
\end{tabular}

Figure 12 Table of results from SORFC cell life cycle testing. (Test number $2^{P t}$ is Platinum baseline cell) 
The first two cells were tested using baseline platinum electrodes on both sides of the cell. SORFC-002 went through Life Cycle Testing with an initial cycle efficiency of $71.6 \%$ and a degradation rate of $4 \%$ per 1000 hours. This cell met the initial performance goals, but degraded at twice the target rate. Nevertheless this baseline cell set the standard for the subsequent tests without the use of precious metals.

SORFC tests 003-016 demonstrated the effect of various non-noble metal electrode catalysts. All these cells tested different electrode configurations except for SORFC-003 and 004, as well as SORFC-011 and 014 which tested the same catalysts. SORFC-003 and SORFC-004 used standard SOFC electrodes that were developed for the company's SOFC program. These two cells were tested using two different manifold materials. It was found that under electrolysis operation the SOFC oxidant catalyst on both these cells completely delaminated from the electrolyte. It therefore became very obvious that the oxidant catalyst required improved adhesion to the electrolyte in order to withstand electrolysis operating conditions.

SORFC-005 had an improved oxidant electrode which remained bonded to the electrolyte throughout the regenerative operation, however the large degradation rate was attributed to the fuel catalyst which required further improvement. SORFC-006 was the first cell with the improved fuel catalyst which operated over $82 \%$ efficient at $100 \mathrm{~mA} / \mathrm{cm}^{2}$ and had a degradation rate similar to the noble metal baseline cells. All subsequent tests were conducted with this same fuel catalyst and so the variations in performance from tests 006 - 016 can be attributed to the cathode catalyst.

SORFC-007 operated for more than 1400 hours at high efficiency with a low degradation rate in the order of $1 \%$ per 1000 hours. A very low degradation rate of $0.7 \%$ per 1000 hours was seen on SORFC-008 from start to finish, however it performed at a lower efficiency.

SORFC-011 produced the highest cycle efficiency of the set with initial values as high as $85 \%$. However, electrochemical stability was not obtained until 300 - 400 hours of operation where the efficiency dropped to $83.2 \%$. After such time the degradation rates were extremely good at less than $0.5 \%$ per 1000 hours. Because this catalyst configuration showed very good promise it was repeated in SORFC-014 which again showed similar behavior at $100 \mathrm{~mA} / \mathrm{cm}^{2}$. At 500 hours the current density was increased to $200 \mathrm{~mA} / \mathrm{cm}^{2}$ with an EVE of $66.2 \%$, however a slight increase in the degradation rate by approximately $1 \%$ per 1000 hours was observed.

It has been encouraging to note that the degradation rate does not necessarily increase substantially with an increase in current density for certain catalyst combinations. The steady state current density of SORFC-013 was tripled without any noticeable impact on the degradation rate, as seen in Figure 13. Steady state operation occurred between 600 1200 hours when the cell voltage stabilized after initial conditioning, which produced degradation rates around $0.5 \%$ per thousand hours. 


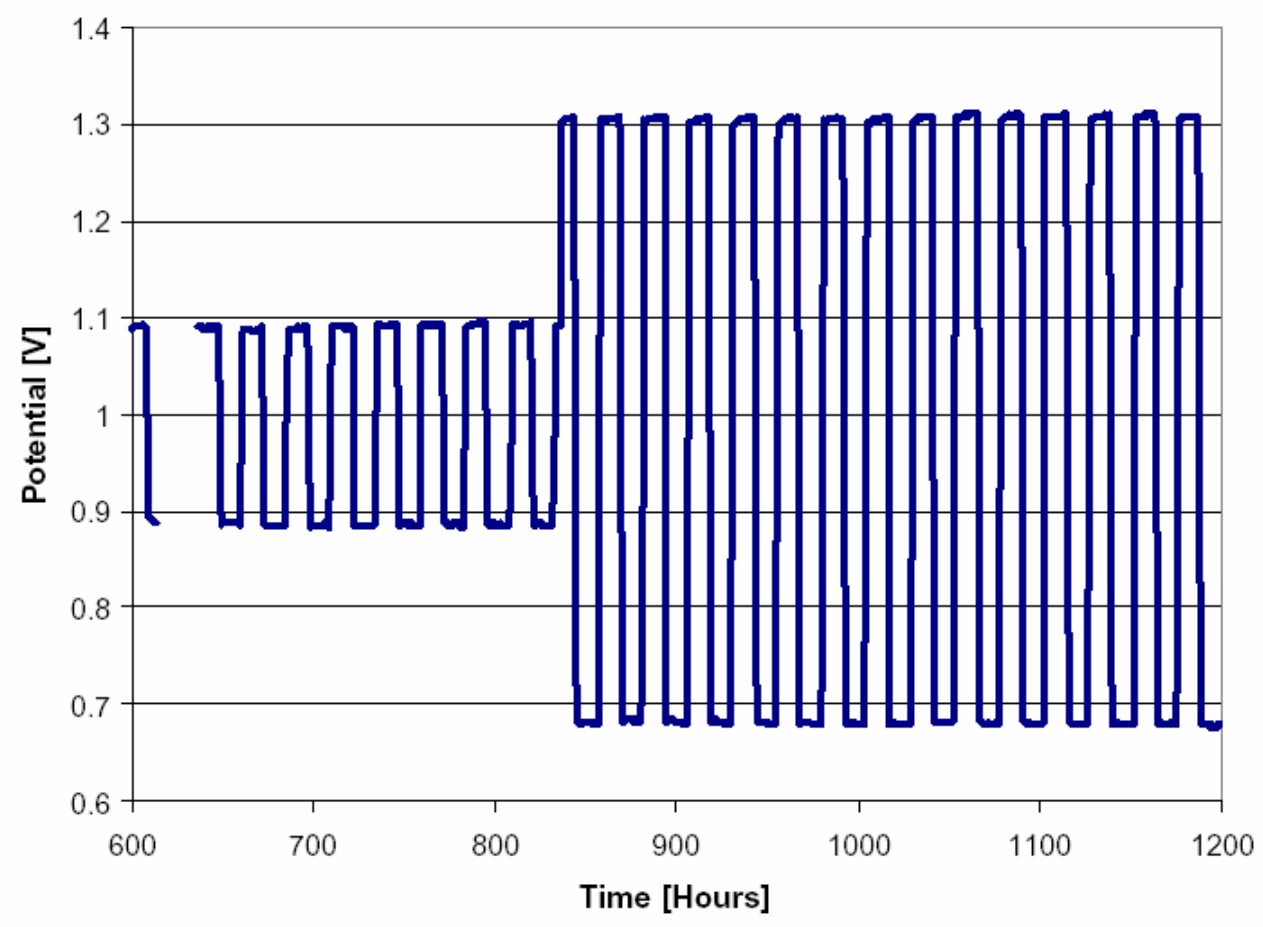

Figure 13 SORFC-013 Life Cycle Test at $850^{\circ} \mathrm{C}, 30 \%$ steam $/ 300 \mathrm{sccm} \mathrm{H}_{2}$ flow, $750 \mathrm{sccm}$ air flow. The cell was operated at $100 \mathrm{~mA} / \mathrm{cm}^{2}$ from 100-836 hours, then at $300 \mathrm{~mA} / \mathrm{cm}^{2}$ from $836-1200$ hours. Potential above $1.0 \mathrm{~V}$ represents the charge or electrolysis mode, below $1.0 \mathrm{~V}$ represents the discharge or fuel cell mode.

The latest cell tested was SORFC-016 which displayed a very good combination of performance and degradation. The initial polarization curve is shown in Figure 14 and it exhibits almost a straight line characteristic from $0.5-1.8 \mathrm{~V}$ across the range from charge to discharge mode. It is this highly reversible characteristic which makes the solid oxide technology an ideal choice for regenerative applications. The life cycle plot can be seen in Figure 15, which indicates that doubling the current density to $200 \mathrm{~mA} / \mathrm{cm}^{2}$ did not effect the degradation rate which was steady at $2 \%$ per thousand hours.

The various different oxidant catalyst compositions can be directly compared to one another from SORFC-006 to SORFC-016 because they were all tested under identical conditions with the same catalyst on the fuel side. Figure 16 shows the electrolysis power curve for these cells at the 200 hour operation mark. Here it is seen that all cells produced similar power consumption characteristics except for SORFC-008, 009 and 010 which produced poorer performances. The fuel cell operation produced more of a spread of performances as seen on Figure 17. However around the operating current densities of interest at $200 \mathrm{~mA} / \mathrm{cm}^{2}$ (2A for the $50 \mathrm{~mm}$ cells) all cells again fall within a tight band except for the lower performances of SORFC-008, 009 and 010. Therefore we can see that even with very different catalyst compositions the performance spread observed was very small 


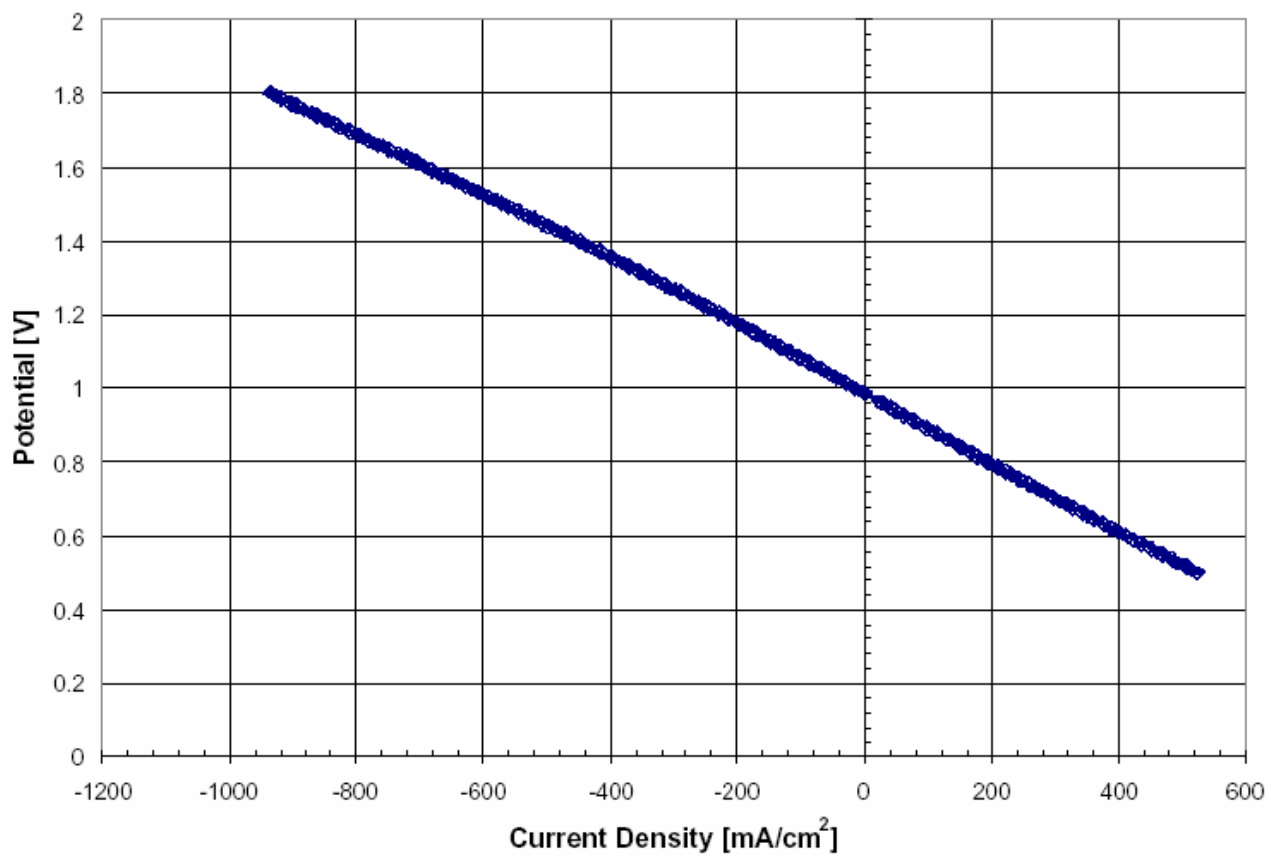

Figure 14 SORFC-016 Initial Polarization Curve at 120 hours. The test conditions were $850^{\circ} \mathrm{C}, 30 \%$ steam $/ 300 \mathrm{sccm} \mathrm{H}_{2}$ flow, $750 \mathrm{sccm}$ air flow. Positive current represents the discharge or fuel cell mode, negative current represents the charge or electrolysis mode.

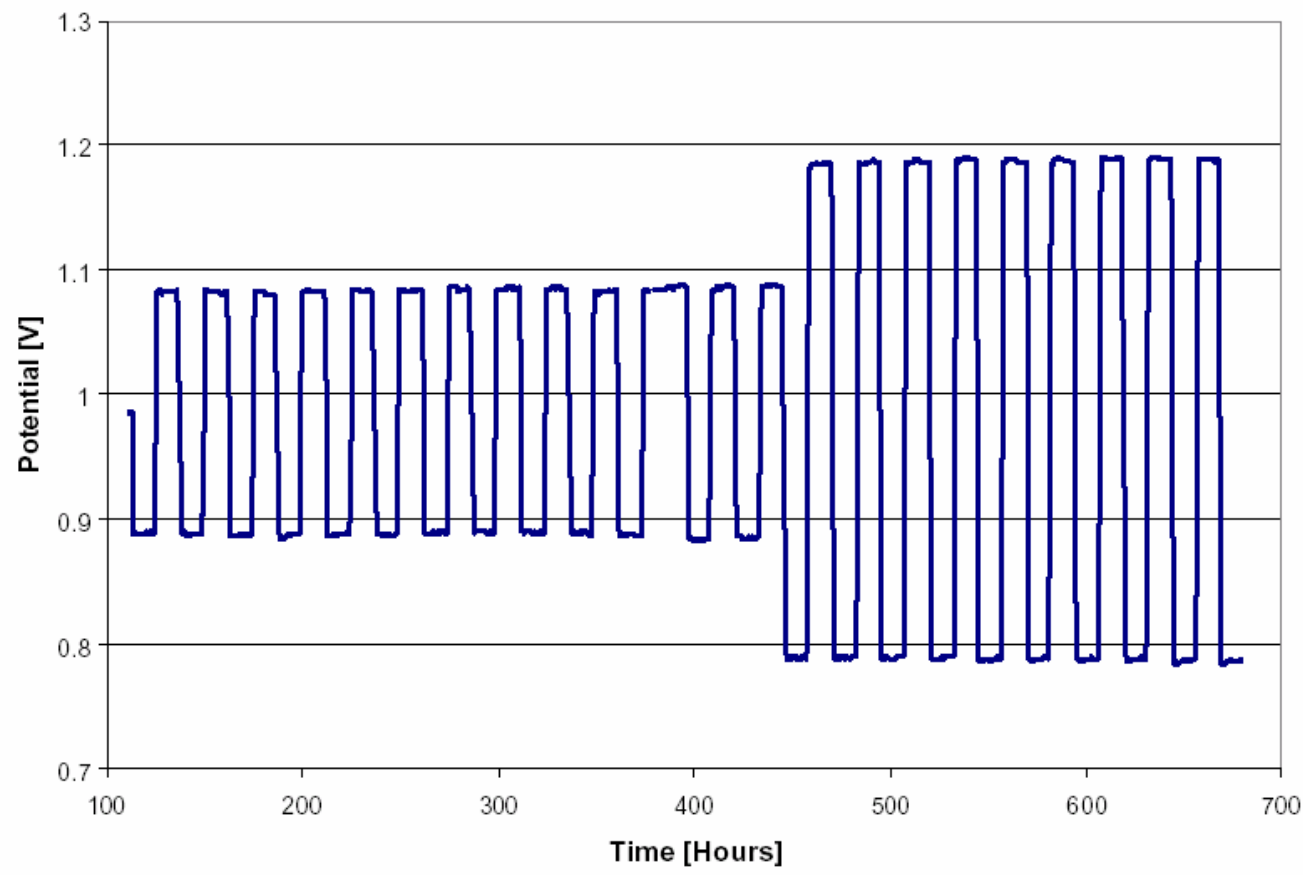

Figure 15 SORFC-016 Life Cycle Test at $850^{\circ} \mathrm{C}$, 30\% steam $/ 300 \mathrm{sccm} \mathrm{H}_{2}$ flow, $750 \mathrm{sccm}$ air flow. The cell was operated at $100 \mathrm{~mA} / \mathrm{cm}^{2}$ from $120-450$ hours, then at $200 \mathrm{~mA} / \mathrm{cm}^{2}$ from $450-680$ hours. Potential above $1.0 \mathrm{~V}$ represents the charge or electrolysis mode, below $1.0 \mathrm{~V}$ represents the discharge or fuel cell mode. 


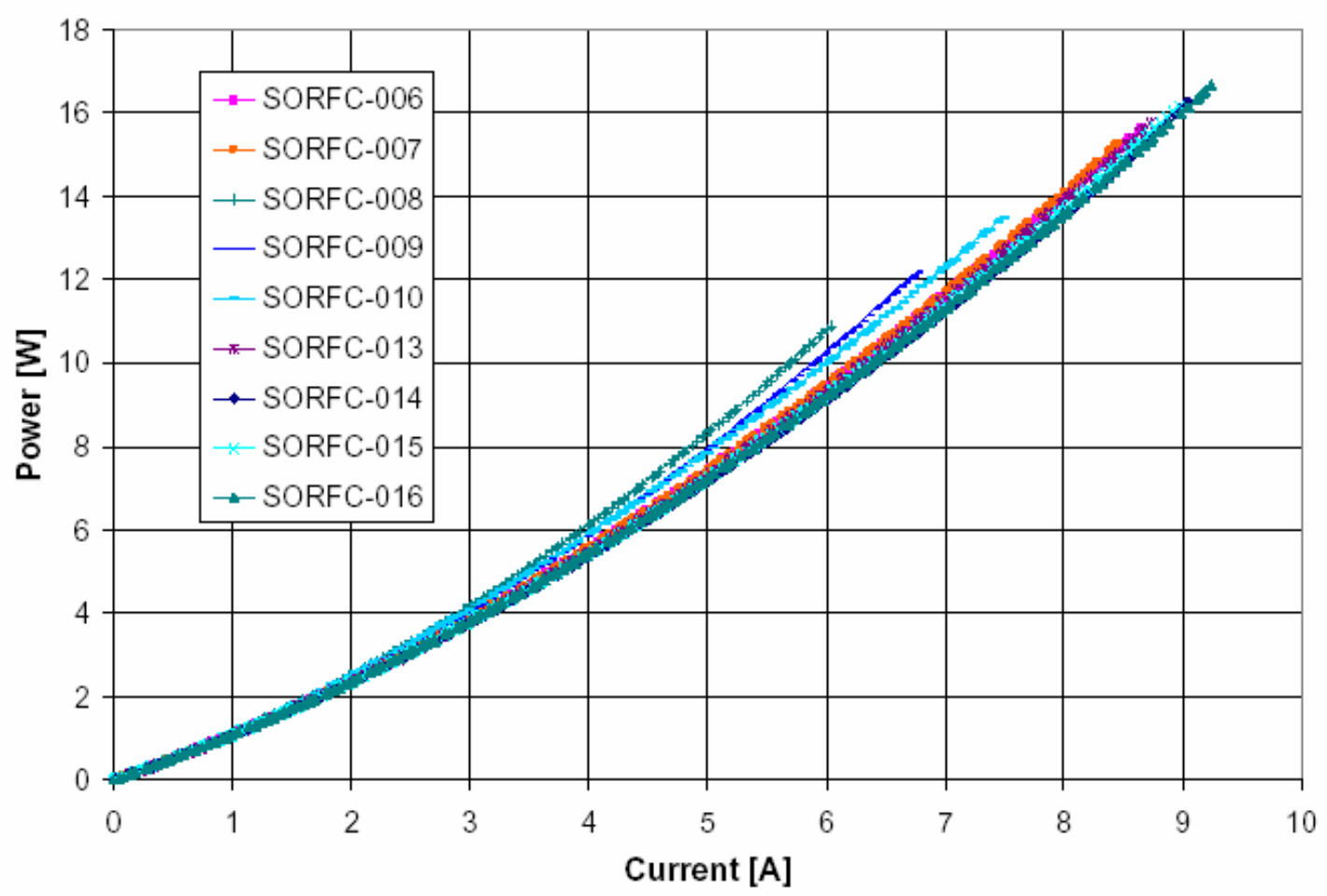

Figure 16 Comparison of oxidant catalyst compositions in electrolysis mode at 200 Hours and $850^{\circ} \mathrm{C}$. Active Area of $10 \mathrm{~cm}^{2}, 30 \%$ Steam $/ 300 \mathrm{sccm} \mathrm{H}_{2}, 750 \mathrm{sccm}$ Air

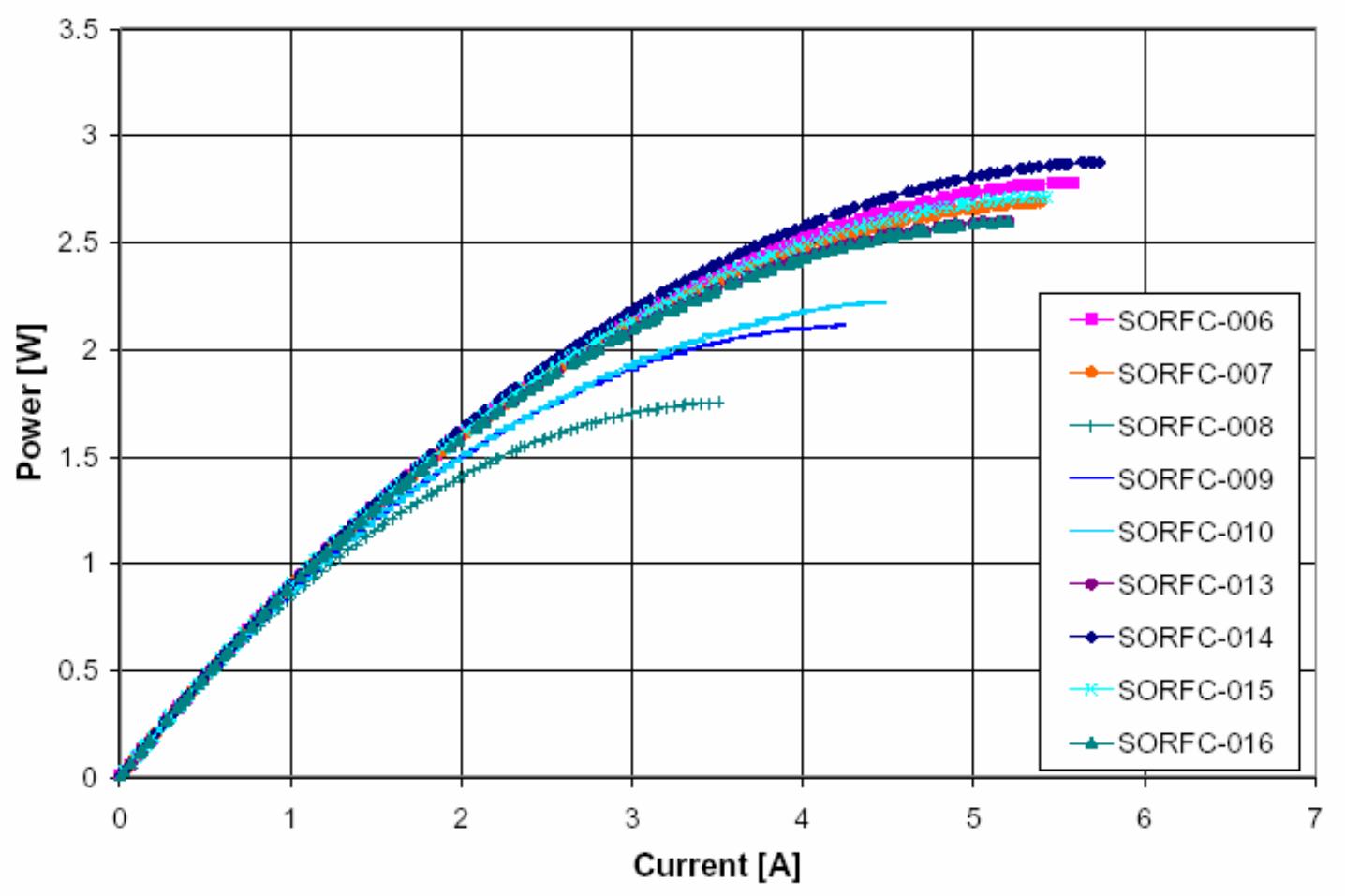

Figure 17 Comparison of oxidant catalyst compositions in fuel cell mode at 200 Hours and $850^{\circ} \mathrm{C}$. Active Area of $10 \mathrm{~cm}^{2}, 30 \%$ Steam $/ 300 \mathrm{sccm} \mathrm{H}_{2}, 750 \mathrm{sccm}$ Air 


\subsection{Thermal Storage}

Several thermal storage techniques were initially considered, including adsorption-based, absorption-based, chemical reactions, and the use of phase change materials (PCMs). Sensible heat storage was not considered due to the relatively large volume of material required, compared with PCM. Thermal storage via chemical reactions was reviewed [OTA, Perret], but appropriate chemical reactions were not found for this application (e.g., highly reversible and near completion at the two temperatures of interest $800^{\circ} \mathrm{C}$ and $900^{\circ} \mathrm{C}$ ). Most of the thermal storage techniques reviewed, including absorption-based cycles and adsorption-based cycles were not capable of providing the high quality heat necessary for maintaining the reaction zone at operating temperature during electrolysis, although several techniques could be used to convert liquid water to steam. Two adsorption-based techniques useful for converting liquid water to steam are described in the following paragraphs. However, for our detailed study, we chose to focus on PCMs with the highest volumetric energy density.

Adsorption-based heat storage was considered using a zeolite bed and carbon dioxide. The system consists of a gas storage tank connected to a zeolite bed with a metering valve in the connection line. The working fluid is carbon dioxide and the zeolite bed is thermally coupled to the SORFC. When the SORFC is in the fuel cell mode, carbon dioxide, previously adsorbed into the zeolite, is desorbed using the fuel cell waste heat thereby raising the carbon dioxide pressure. The interconnecting valve is opened to allow the storage tank to be pressurized with carbon dioxide. At the end of the fuel cell mode operation the interconnecting valve is closed locking in the high pressure carbon dioxide. In electrolysis mode, high pressure carbon dioxide is metered into the zeolite bed causing a significant temperature increase (heat of adsorption). The water reactant is thermally coupled to the zeolite resulting in vaporizing and/or raising the temperature of the water vapor. Overall the cycling of the tank/zeolite bed system adsorbs fuel cell waste heat and returns this heat to the system during the electrolysis operation. This cycle is not capable of providing the high quality heat necessary for maintaining the reaction zone at operating temperature during electrolysis, although it could be considered as a way to provide the heat of vaporization to convert liquid water to steam.

Adsorption-based thermal storage was considered using hydrides. The hydride system consists of a gas storage tank filled with a hydride (e.g., magnesium hydride). The working fluid is the reactant/product hydrogen and the hydride is thermally coupled to the SORFC. Upon adsorbing hydrogen a large quantity of heat is generated, upon removing hydrogen a large quantity of heat must be added [Noritake, Sandrock]. This cycle is synergistic with the needs of the SORFC (i.e. fuel cell waste heat adsorbed during fuel cell mode and heat generated during the electrolysis mode). This cycle is not capable of providing the high quality heat necessary for maintaining the reaction zone at operating temperature during electrolysis, although it could be considered as a way to provide the heat of vaporization to convert liquid water to steam. This cycle has additional merit for SORFC systems if hydrides are used for hydrogen storage. Selection of hydrogen storage technique is beyond the scope of the project. 
Thermal storage with high quality heat can be achieved with PCMs. The phase change can be liquid/vapor, solid/liquid, or a change in crystal structure. Solid/liquid transitions tend to have the highest volumetric thermal storage density, so we limited our literature search to this class of PCM. In the SORFC case we have considered the idea of using a single PCM or multiple PCMs in flow series with increasing phase change temperatures. In fuel cell mode the air exhaust would be above the highest temperature PCM. When the air exhaust temperature falls below its phase change temperature, the air exhaust is in thermal communication with the next PCM and so on down the flow path of lower and lower phase change temperature materials. At the end of the fuel cell run all of the PCMs would be in the liquid state. In electrolysis mode the process water would flow in thermal communication in the direction starting from the lowest phase change temperature material toward the highest phase change temperature material. Water vapor entering the SORFC stack would have a temperature of approximately equal to the highest temperature PCM. As electrolysis proceeds in an endothermic manner, the cell will be cooled such that the hydrogen outlet temperature is slightly below the highest temperature PCM. Since the addition of each PCM adds complexity and volume, for this study we limited our investigation to a single PCM with solid/liquid phase change within the SORFC operating temperature range.

NASA has an extensive database for solar thermal dynamic power plants which are operated with temperatures comparable to those we are considering. Possible PCMs with melting points in the range of $800-900^{\circ} \mathrm{C}$ include carbonates, chloride salts, fluoride salts, and fluoride salt mixtures. Examples of each are listed in Figure 18.

\begin{tabular}{|c|c|c|c|c|c|}
\hline $\begin{array}{l}\text { Phase Change } \\
\text { Material }\end{array}$ & $\begin{array}{c}\text { Melting } \\
\text { Temperature } \\
\text { Tmelt }[\mathrm{C}]\end{array}$ & $\begin{array}{l}\text { Liquid Density } \\
\text { at Tmelt } \\
\text { [g/cc] }\end{array}$ & $\begin{array}{c}\text { Latent Heat of Fusion } \\
\text { Gravimetric } \\
{[\mathrm{kJ} / \mathrm{g}]}\end{array}$ & $\begin{array}{c}\text { Latent Heat of Fusion } \\
\text { Volumetric, liquid at Tmelt } \\
{[\mathrm{kJ} / \mathrm{cc}]}\end{array}$ & References \\
\hline LiF & 848 & 1.83 & $1.044-1.08$ & $1.91-1.98$ & Annex 10, Misra, OTA, Yaffe \\
\hline NaF-25\%MgF2 & 832 & 2.19 & 0.626 & 1.37 & Misra, OTA \\
\hline $\mathrm{NaCl}$ & 802 & 1.56 & 0.480 & 0.75 & Herrmann, Van Artsdalen \\
\hline $\mathrm{Na2CO}$ & 854 & 1.97 & 0.265 & 0.52 & Herrmann, Janz \\
\hline
\end{tabular}

Figure 18 Thermal Energy Storage Densities of Several Candidate Phase Change Materials (PCMs)

Data in Figure 18 show that lithium fluoride (LiF) has the highest thermal energy storage density as measured by latent heat of fusion (volumetric for the liquid at the melting temperature) and an ideal melting temperature for the desired operating temperature range $\left(800-900^{\circ} \mathrm{C}\right)$. On this basis, it was chosen for further study in this program. Note that the fluoride salt mixture $\left(75 \% \mathrm{NaF} / 25 \% \mathrm{MgF}_{2}\right)$ was second best [OTA], but it suffers from a high degree of undercooling $(60$ - $80 \mathrm{~K})$ according to [Misra]. This high degree of undercooling makes it too inefficient to use as a PCM for thermal storage. $\mathrm{NaCl}$ and $\mathrm{Na}_{2} \mathrm{CO}_{3}$ have significantly lower thermal energy storage density compared to $\mathrm{LiF}$, but they are significantly less expensive per unit of thermal storage [Herrmann, OTA]. A $1 \mathrm{~kW}$ SORFC stack has been designed considering the use of a maximum of 100 cells, with each cell having an active area of $67 \mathrm{~cm}^{2}$. Using the demonstrated SORFC performance, the $1 \mathrm{~kW}$ should be obtained at a current density between 0.2 and $0.3 \mathrm{~A} / \mathrm{cm}^{2}$. The air cathode flow fields have been configured for a two stoichiometric flow to minimize heat loss from the system during fuel cell mode operation. Two opposite 
surfaces of the stack have been dedicated to the transfer of heat between the SORFC cells and a thermal storage box using a PCM.

Analysis was performed using ASPEN Plus (Aspen Technology's chemical process tool for the design, simulation, and optimization of process plants) and COSMOS Works (a finite element thermal analysis code that plugs into SolidWorks computer aided design package). Our ASPEN Plus analysis (Figure 19) showed that the estimated heat available for thermal storage is $454 \mathrm{~W}$. The estimated heat loss from our thermal storage test setup was $490 \mathrm{~W}$ (using COSMOS Works). The measured heat loss from our thermal storage test setup employing LiF as the PCM was $491 \mathrm{~W}$. According to COSMOS Works, improved insulation could cut our heat loss in half, but that would still a significant fraction of the heat available for storage. This analysis shows that the planned $1 \mathrm{~kW}$ SORFC has too low a rating to be thermally self sufficient with thermal storage alone. For this reason it is planned to continue the project without integrating thermal storage with the $1 \mathrm{~kW}$ stack, but to provide the design features within the stack to allow thermal storage integration in the future when the fuel cell rating is increased to a sufficient level to be thermally self sufficient with thermal storage.

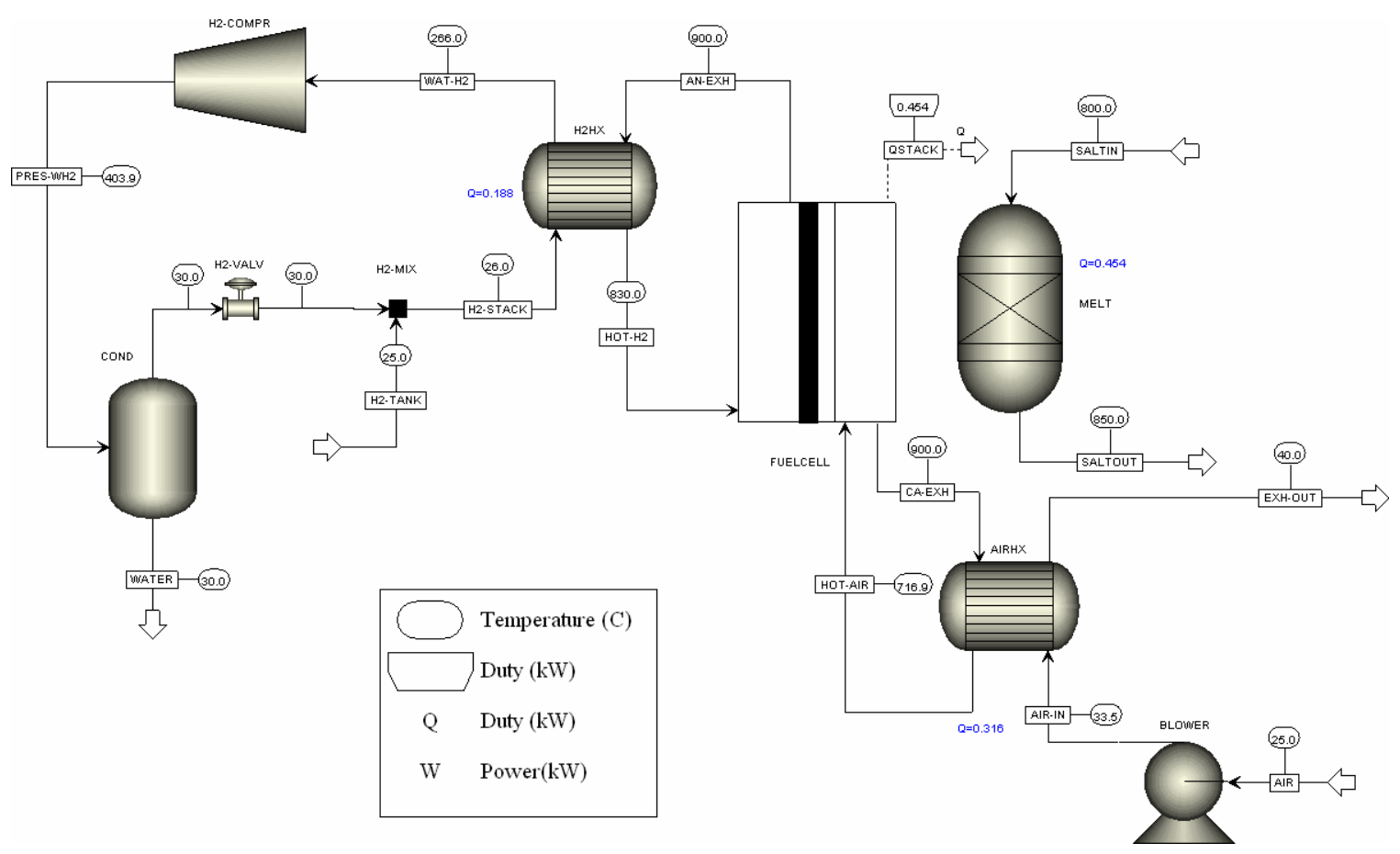

Figure 19 ASPEN Plus model for SORFC system in fuel cell mode shows $454 \mathrm{~W}$ for thermal storage

A typical LiF temperature profile obtained during an experimental run is shown in Figure 20. The LiF is melted by raising the stack simulators surface temperature in steps A thru E. The system is paused during step $\mathrm{F}$ with the $\mathrm{LiF}$ in the liquid phase. The $\mathrm{LiF}$ is allowed to crystallize during step $\mathrm{G}$ by removing power from the heaters in the stack simulators. The points of crystallization onset and completion were estimated by the shape of the crystallization curve and have been defined as points where the temperature 
change rate drops below $\pm 0.004 \mathrm{~K} / \mathrm{s}$. An expanded view of the temperature profiles in step $\mathrm{G}$ during a crystallization experiment is shown in Figure 21. Results of the LiF thermal storage experiment are summarized in Figure 22.

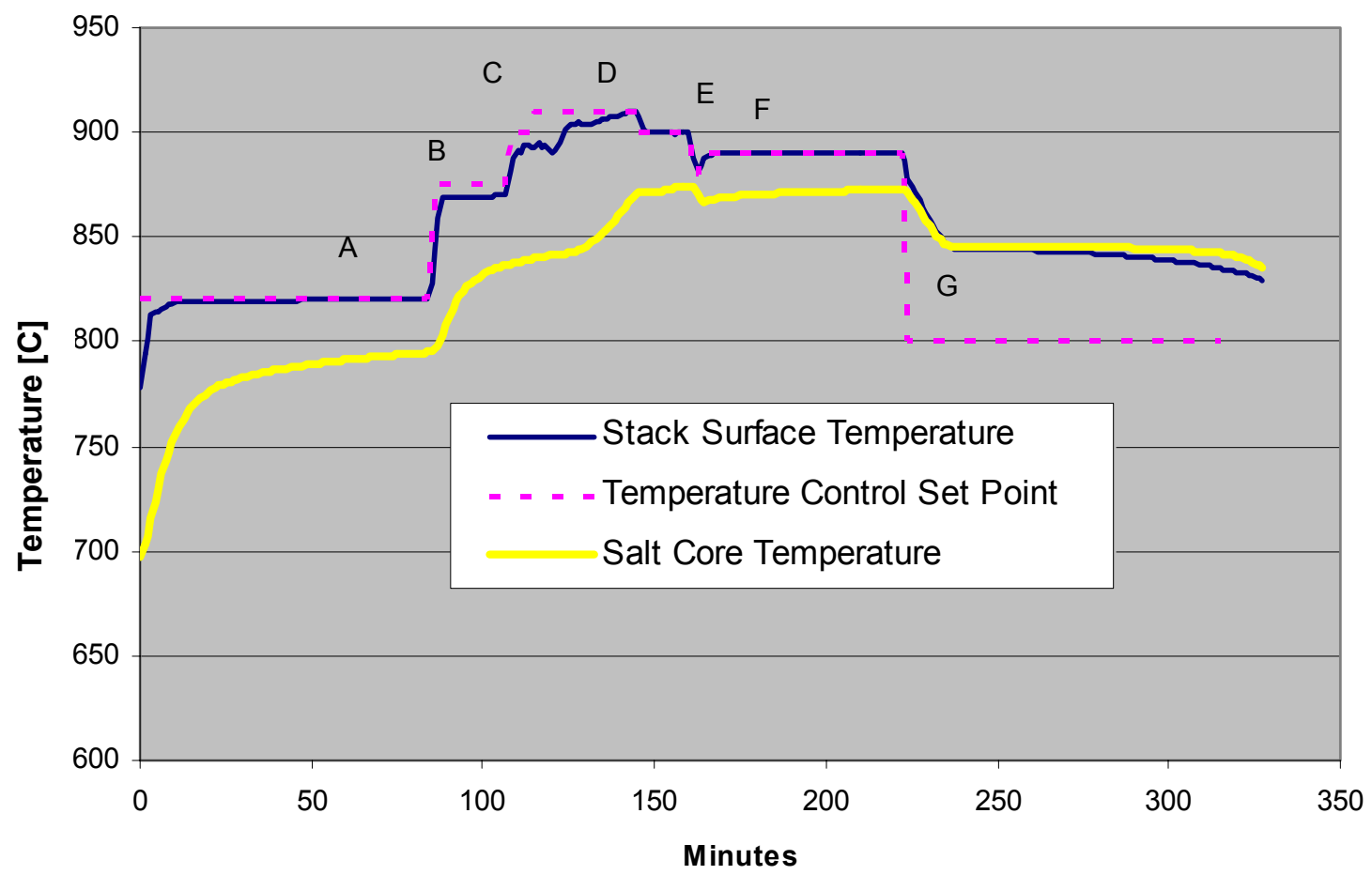

Figure 20 Typical melt and crystallization temperature profiles for a LiF thermal storage experiment

Thermal storage using LiF as a PCM was determined to have the highest volumetric storage density for all techniques reviewed for an SORFC system operating at 800 $900^{\circ} \mathrm{C}$. The thermal power available for storage for a high efficiency SORFC was determined to be $454 \mathrm{~W}$ using ASPEN Plus modeling. The thermal loss for a hot box with dimensions and insulation comparable to what is needed for a $1 \mathrm{~kW}$ SORFC was determined to be $490 \mathrm{~W}$ using COSMOS Works. This was in excellent agreement to the measured $491 \mathrm{~W}$ consumed by the power to the heaters required to maintain temperature slightly above the $\mathrm{LiF}$ melting point of $848^{\circ} \mathrm{C}$. The estimated thermal loss was $1-5 \%$ higher when measured using crystallization time, depending on the value used for latent heat of fusion. This slight discrepancy was likely due to thermal gradients in the LiF resulting from void formation as the $\mathrm{LiF}$ densifies by $\sim 30 \%$ when it solidifies. 


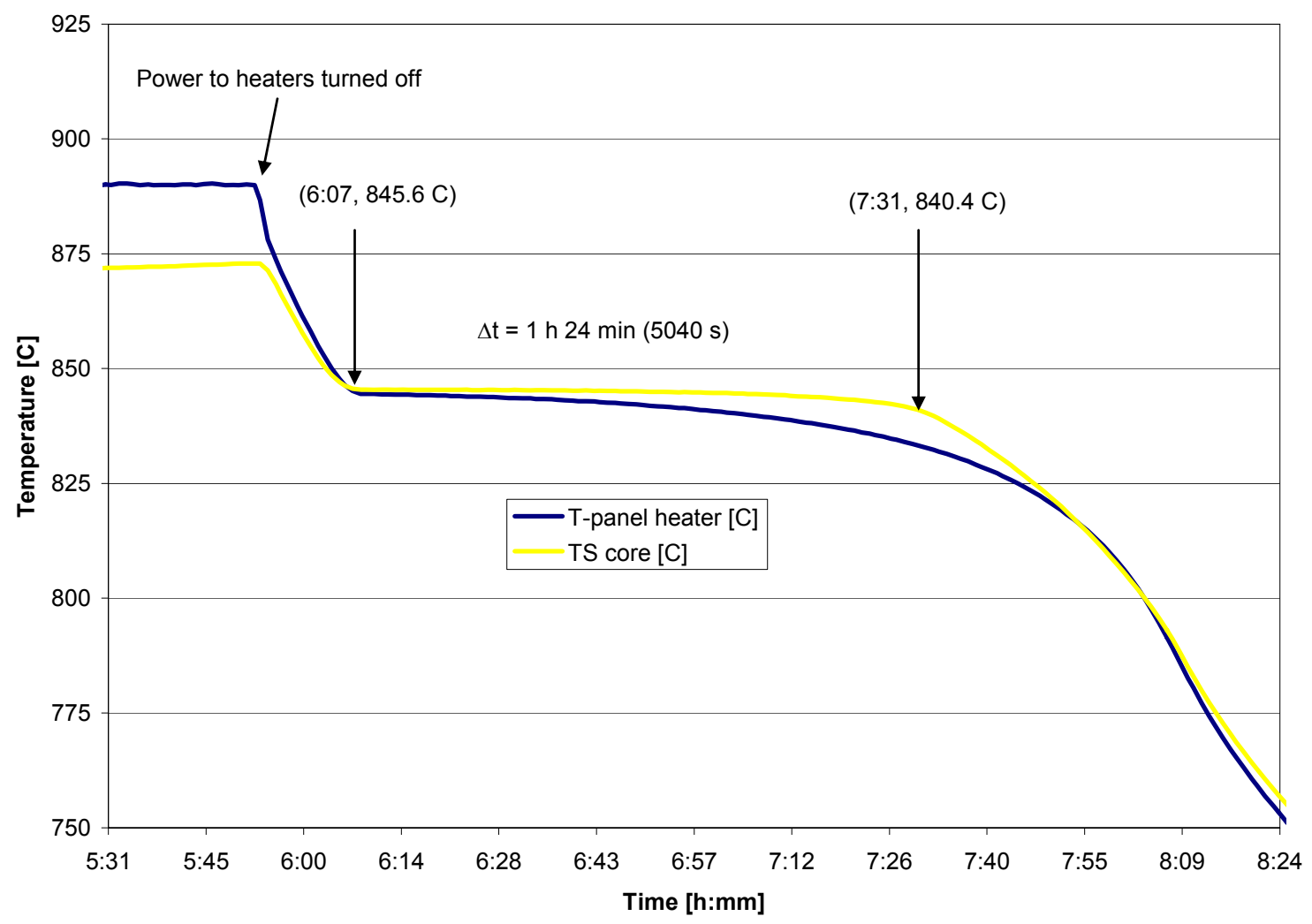

Figure 21 Expanded view of the temperature profiles during LiF crystallization

\begin{tabular}{|c|c|c|c|c|c|c|}
\hline $\begin{array}{c}\text { Heat Losses as } \\
\text { Determined by Heater } \\
\begin{array}{c}\text { Power Consumption } \\
\text { Measurement [W] }\end{array}\end{array}$ & $\begin{array}{c}\text { Crystallization } \\
\text { Time [s] }\end{array}$ & $\begin{array}{c}\text { Mass of LiF } \\
{[\mathrm{kg}]}\end{array}$ & $\begin{array}{c}\text { Latent Heat } \\
\text { of Fusion, } \\
\text { LiF [kJ/g] }\end{array}$ & $\begin{array}{c}\text { Heat Losses as } \\
\text { Determined by } \\
\text { Crystallization Process } \\
\text { Duration [W] }\end{array}$ & $\begin{array}{c}\text { Heat Loss } \\
\text { Estimated by } \\
\text { CoSMOS } \\
\text { Works [W] }\end{array}$ & $\begin{array}{c}\text { Heat Available } \\
\text { to Storage } \\
\text { (Aspen Plus) } \\
\text { [W] }\end{array}$ \\
\hline 491 & 5040 & 2.40 & $1.044-1.08$ & $497-514$ & 490 & 454 \\
\hline \hline
\end{tabular}

Figure 22 Results of the LiF thermal storage experiment

Thermal losses will need to be reduced several-fold, in order to maintain operating temperature in a high efficiency SORFC using thermal storage alone. Additional modeling using COSMOS Works showed that significantly improved insulation can cut losses in half, which is still inadequate for a $1 \mathrm{~kW} \mathrm{SORFC.}$

The heat transfer coefficient between the LiF and the stack simulator surface goes down by almost order of magnitude during the crystallization cycle. The reduced heat transfer in the solid phase is likely due to void formation. Heat transfer can be improved by using a metal mesh immersed in the LiF, as proposed by [Tournier]. 


\subsection{Stack Design}

The SORFC stack was intended to be based on the existing company SOFC stack design with suitable modifications to the electrodes and gas flow field pressure drops. The results to date indicate that standard SOFC electrodes may not be suitable candidates for an SORFC stack as indicated by tests SORFC-003 and SORFC-004 where the SOFC cathode delaminated under regenerative operation. A suitable electrode for the $1 \mathrm{~kW}$ SORFC stack will be identified by the electrode development task. The performance results from this task will also provide the input for the global $1 \mathrm{~kW}$ stack specifications. These specifications are listed in Figure 23.

Both the fuel and oxidant are also different from SOFC stack operation and this may lead to modified flow fields. The oxidant flow in fuel cell mode is required to be very low in order to limit the amount of heat loss in the total system. The heat recovered from the oxidant exhaust heat exchanger is dependant on the heat exchanger effectiveness and the amount of general heat loss to the environment. Because neither of these parameters can ever be ideal it pays to limit the entropy loss by limiting the amount of heat recovery necessary on the air side. This then necessitates the use of high utilization (low stoichiometric) levels on the oxidant side. The fuel side consumes humidified hydrogen as opposed to methane/natural gas in an SOFC system. The gas properties of the fuel are obviously dependant on the hydrogen/steam mixture. The $30 \%$ steam/hydrogen mix happens to have a similar Nernst potential and composition to that of reformed methane, but of course it will have its own inherent properties under operating conditions.

In order for the SORFC stack to operate at low air flow rates the pressure drop across the cells was increased to maintain flow uniformity. This pressure drop increase was achieved by reducing the depth of the air flow channels in the interconnect.

The fuel side flow geometry could be kept similar to the SOFC design and is in fact the fall back option for the $1 \mathrm{~kW}$ stack. However it may be possible to improve the fuel side flow uniformity and contact characteristics with the use of Ni metal foam products. Therefore the first interconnects designed for the stack testing program contains a fuel side cavity to incorporate a nickel foam insert. These nickel foams can be specifically made to optimize porosity, density and thickness. They offer the potential to improve fuel flow uniformity because of their uniform porosity. The other main advantage is the potential to improve the electrical contact with the anode electrode. The uniform surface structure of the foams, provide more contact points with lower lateral conduction losses because of the small distance between each contact point. 


\begin{tabular}{|l|c|}
\hline \multicolumn{2}{|c|}{ 1kW SORFC Stack Specifications } \\
\hline Fuel Composition & $70 \% \mathrm{H}_{2} / 30 \% \mathrm{H}_{2} \mathrm{O}$ \\
\hline Fuel Utilization & $50 \%$ \\
\hline Oxidant & Air \\
\hline Oxidant Stoichiometry & 2 \\
\hline Electrolyte Material & $8 \mathrm{YSZ}$ \\
\hline Electrolyte Thickness & $300 \mu \mathrm{m}$ \\
\hline Current Density & $200 \mathrm{~mA} / \mathrm{cm}^{2}$ \\
\hline Active Area & $65 \mathrm{~cm}^{2}$ \\
\hline Total Stack Current & $13 \mathrm{~A}$ \\
\hline Fuel Cell Operating Voltage & $0.770 \mathrm{~V}$ \\
\hline Electrolysis Cell Operating Voltage & $1.200 \mathrm{~V}$ \\
\hline Electrochemical Voltage Efficiency & $63 \%$ \\
\hline Number of Cells & 100 \\
\hline Fuel Cell Power Output & $1000 \mathrm{~W}$ \\
\hline Electrolysis Power Consumption & $1560 \mathrm{~W}$ \\
\hline Overall Dimensions LxWxH & $100 \times 100 \times 300 \mathrm{~mm}$ \\
\hline
\end{tabular}

Figure 23 Global specifications of the $1 \mathrm{~kW}$ SORFC stack

A small number of interconnects have been fabricated under the stack design task and are available for testing. They incorporate the high pressure drop air side channels with the fuel side cavity for the inclusion of the nickel foam. A picture of both sides of the finished part is shown in Figure 24. It can be seen from the interconnect geometry that the fuel side is internally manifolded and the oxidant side is externally manifolded. External manifolds are not as air tight as internal manifolds, however this configuration is suitable for the SORFC stack because the oxidant exhaust is not required to be collected and the oxidant inlet can tolerate a small amount of leakage without effecting cell performance. However any leakage rates over a few percent on the oxidant side will adversely impact the thermal balance of the stack and so it is important to keep any leakage down to a minimum amount. The internally manifolded fuel side is a very well sealed system with many thousands of hours of demonstrated operation in SOFC stacks. 


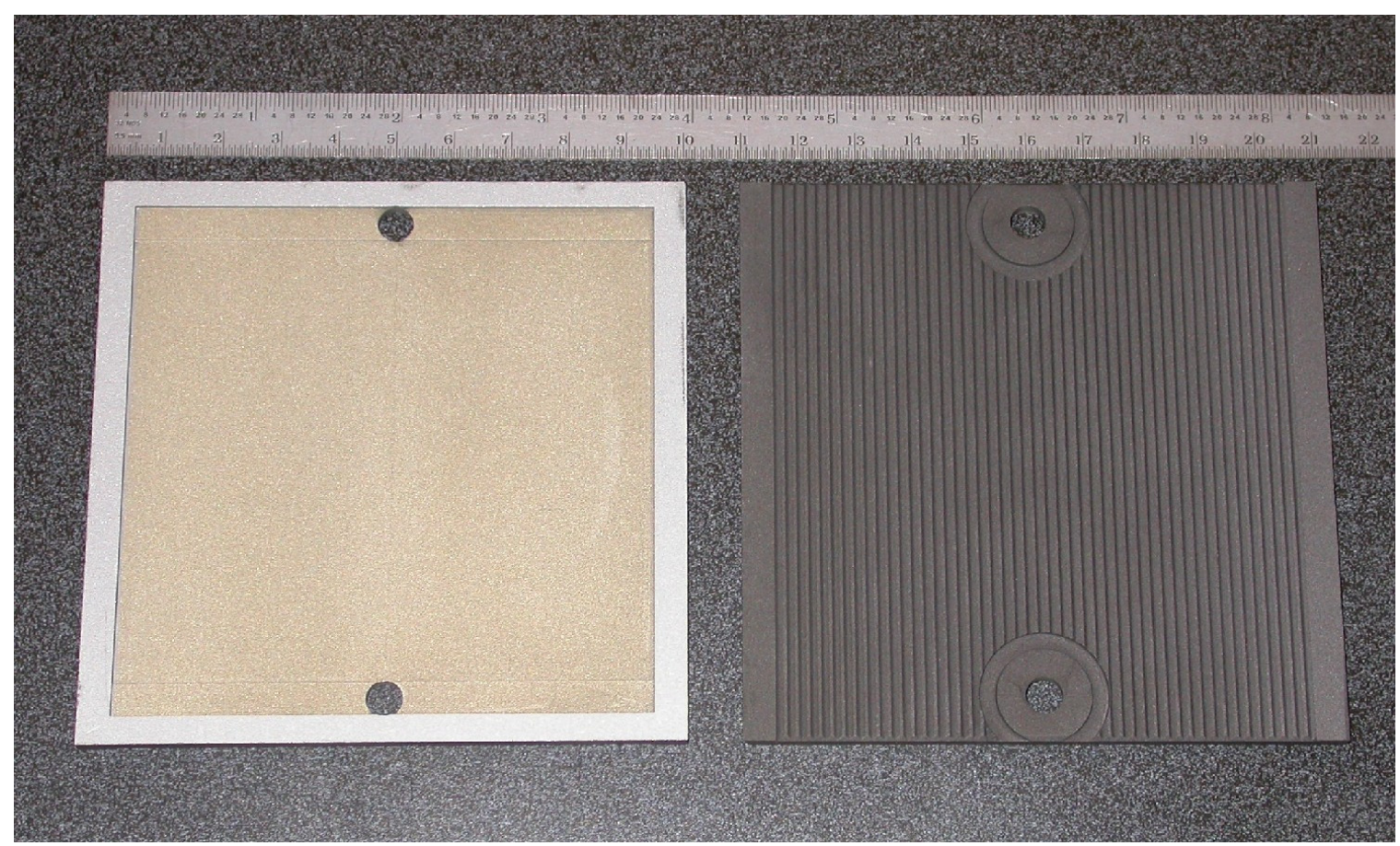

Figure 24 Interconnects fabricated for SORFC stack testing

The flow distribution inside the interconnect plates has a significant effect on the operating efficiency of a reversible system. The pressure drop imparted on the gas streams inside the manifold has to be overcome by blowers and creates parasitic losses. Therefore flow channels should be kept large with minimal pressure drop. On the other hand, flow uniformity within the manifold also plays a major role and flow uniformity can best be engineered with well designed pressure drops forcing equal gas distribution.

The Ion America interconnect was designed based on 1-D laminar channel flow approximations. On the hydrogen/water side of the system the flow is distributed on three distinct levels. The gas is transported along the height of the stack ("vertical") in riser channels with circular cross section. From these riser channels the flow moves lateral in "distribution pockets" from where it is delivered to an array of about 40 parallel channels which cover the cell active area. Without an in-depth analysis it is not clear in how far multi dimensional flow effects modify the flow distribution. CFD calculations were executed in order to study the transitions between the different distribution levels. The simulations were run using a combination of SolidWorks to create the solid model and Cosmos Works for the flow study. The geometry of the internal flow channels is far too complex to simulate a complete multi-layer stack (without engaging today's supercomputers). Therefore the flow field was divided into small segments to study the pressure drop across the channel transitions. The flow inside the stack occurs at low Reynolds numbers. The flow in the riser has a Reynolds number of around 100 and therefore behaves laminar. The flow in the remainder of the stack occurs around Reynolds numbers in the order of one. The CFD simulations confirmed that there are very few 3-D effects in this laminar flow field. 1-D pressure drop models appear appropriate for this kind of flow field. 


\section{CONCLUSION}

The electrode development task has been very successful and in most cases exceeded the projects goals developed at the outset. In fact all cells tested for the program produced initial electrochemical voltage efficiencies (EVE's) in excess of the $70 \%$ target, with eight cells exceeding $80 \%$ voltage efficiency. The cells that were tested at $200 \mathrm{~mA} / \mathrm{cm}^{2}$ in both operational modes also exceeded the $61.5 \%$ EVE target that was specified at $200 \mathrm{~mA} / \mathrm{cm}^{2}$ electrolysis and $100 \mathrm{~mA} / \mathrm{cm}^{2}$ fuel cell modes. All cells tested at $200 \mathrm{~mA} / \mathrm{cm}^{2}$ exceeded $66 \%$ voltage efficiency. A single cell was tested at $300 \mathrm{~mA} / \mathrm{cm}^{2}$ in both modes and produced over $50 \%$ voltage efficiency.

The degradation rates observed were generally very encouraging with seven cells meeting the goals of not more than $2 \%$ degradation rates at $100 \mathrm{~mA} / \mathrm{cm}^{2}$. Two cells with separate electrode configurations also met the $2 \%$ degradation targets at 200 and $300 \mathrm{~mA} / \mathrm{cm}^{2}$. Therefore there are a number of electrode configurations that show good promise as candidates for the $1 \mathrm{~kW}$ stack. In future work there will be an effort to reduce the electrolyte resistance by exploring thinner electrolytes and possibly electrolytes with higher ionic conductivities in order to obtain more resolution between catalyst compositions and increase performance levels. Also the microstructure of the catalysts will be investigated to optimize the electrolyte/electrode interface connectivity, porosity and thickness. These activities are planned to further improve electrode performance and to help target the most optimum catalysts in terms of composition as well as microstructural properties for the forthcoming stack tests in Year 2.

At current performance levels the $1 \mathrm{~kW}$ stack will require 100 layers of the larger footprint $(100 \times 100 \mathrm{~mm})$ sized cells. Increasing the performance levels beyond the current $63 \%$ voltage efficiency at $200 \mathrm{~mA} / \mathrm{cm}^{2}$ will reduce the number of cells required in the $1 \mathrm{~kW}$ stack which will have a very positive impact on reliability, size and cost.

The thermal storage experiments and analysis shows that the planned $1 \mathrm{~kW}$ SORFC has too low a rating to be thermally self sufficient with thermal storage alone. For this reason it is planned to continue the project without integrating thermal storage with the $1 \mathrm{~kW}$ stack, but to provide the design features within the stack to allow thermal storage integration in the future when the fuel cell rating is increased to a sufficient level to be thermally self sufficient with thermal storage.

The tasks to be completed in the next phase of the program will involve a number of scale-up issues, such as the cell footprint, stack size and the electrode ink production. It is desired to move to a thinner electrolyte in order to increase performance by reducing the ionic resistance. This approach will also provide more resolution between electrode compositions for the electrode development task. Stack components have been fabricated and are ready for testing. These interconnect plates will test high pressure drop air channels and nickel foam inserts on the fuel side. 
Generally speaking the SORFC system appears to be a viable technology with many potential applications. The $50 \mathrm{~mm}$ cell tests from the electrode development task have demonstrated impressive stability over time and with further reductions in cell internal resistances, performance levels can approach commercial viability. 


\section{REFERENCES}

1. Annex 10, "Database for phase changing materials, Version I, 990813"; http://www.fskab.com/annex17/Materialdata/Materialdata.xls

2. R.L. Dreshfield, "Long time creep rupture of Haynes alloy 188," NASA Technical Memorandum 107191, Eighth International Symposium on Superalloys, Champion, PA, September 22-26 (1996); http://gltrs.grc.nasa.gov/reports/1996/TM-107191.pdf

3. K. Eguchi, T. Hatagishi, H. Arai, "Power Generation and steam electrolysis characteristics of an electrochemical cell with a zirconia- or ceria-based electrolyte" Solid State Ionics 86-88, 1245-1249 (1996).

4. P.A. Gnadt, "Filling heat storage tubes for solar Brayton-cycle heat receiver with lithium fluoride," Oak Ridge National Laboratory, ORNL-TM-2732, July (1970).

5. U. Herrmann, M. Geyer, and D. Kearney, "Overview on thermal storage systems," Workshop on thermal storage for trough power systems, February 2021 (2002); http://www.eere.energy.gov/troughnet/pdfs/uh storage overview ws030320.pdf

6. G.J. Janz and M.R. Lorenz, J. Electrochem. Soc., 108, 1052 (1961).

7. A.K. Misra, "Fluoride salts as phase change materials for thermal energy storage in the temperature range 1000 - $1400 \mathrm{~K}$," J. Electrochem. Soc., 135, 850 (1988).

8. T. Noritake, M. Aoki, S. Towata, Y. Seno, Y. Hirose, "Charge density analysis in magnesium hydride" R\&D Review of Toyota CRDL 38, 2 (2003);

9. http://www.tytlabs.co.jp/english/review/rev382epdf/e382 015noritake.pdf

10. Office of Technology Assessment (OTA), "Application of solar technology to today's energy needs-Vol. I”, Chapter XI, Energy Storage, 432-464, June (1978); http://www.wws.princeton.edu/cgibin/byteserv.prl/ ota/disk3/1978/7802/780216.PDF

11. R. Perret, R. Boehm, G. Besenbruch, R. Diver, A. Weimer, and A. Lewandowski, "High efficiency generation of hydrogen using solar thermochemical splitting of water,” DOE Hydrogen Program FY 2004 Progress Report, 135-140 (2004); http://www.eere.energy.gov/hydrogenandfuelcells/pdfs/annual04/iig1_perret.pdf

12. G.D. Sandrock and E.L. Huston, "How metals store hydrogen," CHEMTECH 11, 754-762 (1981).

13. J.-M. Tournier and M.S. El-Genk, "Analysis of a lithium fluoride, porous thermal energy storage unit subjected to cyclical thermal loading," Proc. Space Technology and Applications International Forum (STAIF-97), AIP No. 387 (1) 397 - 413, Albuquerque, NM, Jan. 26-30 (1997).

14. E.R.Van Artsdalen and I.S. Yaffe, J. Phys. Chem., 59, 118 (1955).

15. J.D. Whittenberger, "Tensile properties and structure of several superalloys after long-term exposure to LiF and vacuum at 1173 K," J. Mater. Eng. Perf. 4 (1995) 657-73.

16. I.S. Yaffe and E.R.Van Artsdalen, Chem. Div. Semiann. Prog. Rep. ORNL-2159, 77 (1956).

17. A. Yamashita, H. Tsukuda and T. Hashimoto; "Anodic and cathodic electrode reaction at $\mathrm{La}_{1-\mathrm{x}} \mathrm{Sr}_{\mathrm{x}} \mathrm{MnO} 3$ ” Proc. $1^{\text {st }}$ European SOFC Forum, Ed. U. Bossel, 661, (1994). 


\section{LIST OF ACRONYMS AND ABBREVIATIONS}

\begin{tabular}{|c|c|}
\hline CFD & computational fluid dynamics \\
\hline EVE & electrochemical voltage efficiency \\
\hline $\mathrm{F}_{2}$ & fluorine \\
\hline GDC & gadolinia doped ceria \\
\hline $\mathrm{HF}$ & hydrofluoric acid \\
\hline $\mathrm{H}_{2}$ & hydrogen \\
\hline $\mathrm{H}_{2} \mathrm{O}$ & water \\
\hline LCC & lanthanum calcium chromite \\
\hline $\mathrm{LiF}$ & lithium fluoride \\
\hline LSC & lanthanum strontium chromite \\
\hline LSCF & lanthanum strontium cobalt ferrite \\
\hline LSM & lanthanum strontium manganite \\
\hline MIEC & mixed ionic/electronic conductors \\
\hline $\mathrm{MgF}_{2}$ & magnesium fluoride \\
\hline $\mathrm{NaCl}$ & sodium chloride \\
\hline $\mathrm{Na}_{2} \mathrm{CO}_{3}$ & sodium carbonate \\
\hline $\mathrm{NaF}$ & sodium fluoride \\
\hline NASA & National Aeronautics and Space Administration \\
\hline $\mathrm{OCV}$ & open circuit voltage \\
\hline PCM & phase change material \\
\hline $\mathrm{Q}_{\mathrm{E}}$ & heat from endothermic reaction \\
\hline $\mathrm{Q}_{\mathrm{L}}$ & heat losses \\
\hline $\mathrm{Q}_{\mathrm{S}}$ & latent heat from thermal storage \\
\hline $\mathrm{sccm}$ & standard centimeter cubed per minute \\
\hline ScSZ & scandia stabilized zirconia \\
\hline SOFC & solid oxide fuel cell \\
\hline SORFC & solid oxide regenerative fuel cell \\
\hline $\mathrm{T}$ & temperature \\
\hline $\mathrm{t}$ & time \\
\hline $\mathrm{TC}$ & thermocouple \\
\hline 8YSZ & $8 \%$ doped yttria stabilized zirconia \\
\hline $3 \mathrm{YSZ}$ & $3 \%$ doped yttria stabilized zirconia \\
\hline
\end{tabular}

